$1-15-2019$

\title{
Corruption, state capture, and the effectiveness of anticorruption agency in post-communist Ethiopia
}

Seid Y. Hassan Ph.D.

Murray State University, shassan@murraystate.edu

Follow this and additional works at: https://digitalcommons.murraystate.edu/faculty

Part of the Business Law, Public Responsibility, and Ethics Commons

\section{Recommended Citation}

This is an Accepted Manuscript of an article published by Taylor \& Francis in Economic and Political Studies on January, 15, 2019, available online: https://www.tandfonline.com/doi/full/10.1080/20954816.2018.1535757

This Journal Article is brought to you for free and open access by Murray State's Digital Commons. It has been accepted for inclusion in Faculty \& Staff Research and Creative Activity by an authorized administrator of Murray State's Digital Commons. For more information, please contact msu.digitalcommons@murraystate.edu. 
Hassan: Corruption, State Capture and the Effectiveness of Anti-Corruption Agency in PostCommunist Ethiopia

\author{
Seid Y, Hassan* \\ Professor of Economics \\ The Arthur J. Bauernfeind College of Business \\ 307 Business BLDG North \\ Murray State University \\ Murray, KY 42071, USA \\ shassan@murraystate.edu
}

\begin{abstract}
In 2001, Ethiopia established a centralized anti-corruption agency (ACA), the Federal Ethics and Anti-Corruption Commission (FEACC) (see, Proclamation Nos. 433/2005 and 882/2015), purportedly to be used for curbing the rampant corruption. By the government's repeated admissions, corruption continues to engulf the country, indicating the failure of the FEACC to curb corruption. Various researchers attribute the FEACC's failures to curb corruption to a host of reasons that many anticorruption initiatives have fallen apart. This paper follows a different route to show why the FEACC was doomed to fail from the outset. First, we show that the FEACC is indeed a generic anticorruption agency (ACA) largely based on the principal-agent model of corruption. We deploy some testable hypotheses to explore the scenarios under which an anti-corruption agency would be effective. We show that the war against corruption in Ethiopia collapsed mainly because of mischaracterization of the nature of corruption in the country and how the FEACC was established: a conventional anti-corruption agency for a non- conventional problem of corruption. Drawing from the corruption literature of post-communist countries, the paper shows that corrupt Ethiopian practices can easily be subsumed under an extreme version of the highest form of corruption known as state capture. The paper then moves onto unpacking the systemic and predatory nature of the Ethiopian corruption conundrum and how the FEACC approached in tackling it. Doing so allows us to illustrate the endogenous nature of the country's corruption patterns and why a traditional ACA is incapable of tackling a state-driven patronage. It also lays out the flawed structures and practices of the FEACC showing why, under a state enginnered corruption conundrum, the FEACC was doomed to fail from the start. The paper concludes by illustrating the detrimental effects of using the agency as a political weapon to neutralize the ruling party's political opponents as well as the failure of the war against corruption. It calls for a different approach in combating the Ethiopian systemic corruption, a governance regime change being one of them.
\end{abstract}

Key Words: Corruption, State Capture, administrative corruption, post-communist transition, anticorruption agency, principal-agent theory

JEL Classification: D4; D73; F23, F55, K22. K23, K34, H11; H22, H23, H63, K34, L14, L44, L22, L24, L53, O17; O25, O55, P33, K42

\title{
I. Introduction
}

\footnotetext{
*CONTACT: Seid Y. Hassan, Department of Economics \& Finance, Murray State University, Murray, USA shassan@murraystate.edu

I thank the anonymous reviewer at EPS for useful, and insightful and detailed comments and suggestions. The remaining errors are definitely mine.
} 
Hassan: Corruption, State Capture and the Effectiveness of Anti-Corruption Agency in PostCommunist Ethiopia

During the 1996 Annual Joint Meeting of the World Bank and the IMF, and in apparent recognition that foreign aid was becoming the major culprit behind the corruption conundrum in the developing countries (see, for example, Svensson 2000; Alesina and Weder 1999), the then World Bank President, James D. Wolfensohn implored Meeting participants to consider dealing with "the cancer of corruption." Building on his predecessor's declaration, Paul Wolfowitz, another former president of the Bank, declared zero tolerance on developing country-related corruption, to the extent of withholding loans (unsuccessfully ${ }^{2}$ ) to some aid-recipient countries (Marquette 2007). Since then, the Bank and several bilateral aid agencies have helped countries establish a plethora of donor-funded anti-corruption agencies (ACAs), all devoted to the prevention and combating of corruption. These actions were followed by mechanisms and guidelines of establishing anti-corruption agencies (see, for example, World Bank, 2000; n.d.; USAID 2006; UNDP 2014).

One of the main theoretical foundations and policy prescriptions behind the use and establishment of an anti-corruption agency is the well-known two-tier hierarchy principal-agent (PA) or the Klitgaard (1988) three-tier hierarchy principal-agent-client (PAC) theory. It is assumed, in both cases, that the principal has transferred responsibilities to the agent, and it is not always possible for the principal to perfectly monitor the indiscretions of the agent. In the two-tier model, the principal is usually the leader of a nation (benevolent leader embodying the public interest). In some cases, citizens as a whole are assumed to possess sovereign power acting as principals. In some other models, the state itself is the principal. The principal could also be the leader of a country who would be held accountable for his agent's misbehaviors, come election day. The agents are either the lower-level bureaucrats or corrupt politicians possessing insider information. In a sense, the agents are delegates of the principal, the latter passing on some or all of his discretionary power to the agents. Under the PAC model, the principal is once again the leader of the nation, the state or the voters. The agents are assumed to be the lower level corrupt bureaucrats or representatives who are accountable for their actions but may use their discretionary power unscrupulously by creating extra hurdles and extort bribes from private individuals for private gain. The clients are individuals or firms seeking public services. The theory assumes a divergence of interest between the principal and the agents, the latter possessing more discretionary powers and information than the principal. In standard PA/PAC theory, collusion takes place between the agents and clients/outsiders. Asymmetric information (agents possessing superior information and expertise over the principal), opacity and divergence of interests create opportunities for corruption. The aim, therefore, is to bridge the gaps of divergence of interests.

Two important assumptions (implicit and in some cases explicit) subsumed under the principalagent models, and the establishment of ACAs are that corruption stems from individual deviance and weaknesses in a country's institutions. Institutional weaknesses may include ordinary law enforcement agencies and the personnel under them (judges, police officers, prosecutors and other law-enforcement personnel) being corrupt, thereby tainting the entire law enforcement sectors of the government. An independent anti-corruption agency, therefore, plays a role in reducing the discretionary powers (by taking some of the public service delivery away from officials, particularly the courts and the police) and in increasing the risk of being caught with corruption. That is, setting up an anti-corruption agency helps the "principal" detect, investigate, and prosecute unscrupulous agents, thereby discouraging rentseeking and corruption, while at the same time reducing the monopoly/discretionary powers of the rent-seeking agents and informational asymmetry.

\footnotetext{
2 See this illuminating commentary by Francis Fukuyama in regards to why the Bank fails to curb corruption.
} 
Hassan: Corruption, State Capture and the Effectiveness of Anti-Corruption Agency in PostCommunist Ethiopia

Perhaps due to its popularity, particularly in the fields of economics and political science, Klitgaard's (1988) PA/PAC model has seen its days of modifications and extensions (Groenendijk 1997). Indeed, different authors have developed variations of the principal-agent theory, resulting in a family of models (see, for example, Groenendijk 1997; Marquette and Peiffer 2015; Carr 2009; Glória and da Cunha 2015; Gallimard 2012; Persson et al. 2013). It is this principle and a family of models, which are behind the push to establish anti-corruption agencies.

However, developing countries may lack the necessary resources and expertise for incentivizing or rewarding agents and set up the required anti-corruption agency, which in turn can monitor and punish corrupt agents. This gap is filled by multinational agencies and donor nations (Jacobs and Wagner 2007: 328). Consequently, we now have a mushrooming anti-corruption industry constantly pushed not only by the World Bank and the United Nations but also by individual country-aid agencies such as the

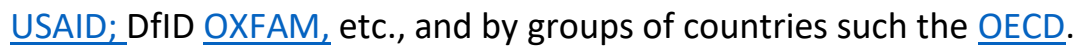

In regards to foreign aid recipient countries, setting up ACAs are usually accompanied by the push for institutional, administrative and economic structural reforms- all geared towards decentralization and hence reduction of the agents' discretionary powers. Though not always successful, multinational aid institutions and bilateral aid agencies (and even NGOs such as Transparency International-TI) are also observed pushing for the "reinvigoration" of a country's political system since corruption is a symptom of governance problems (Heilbrunn 2004.) These include: allowing political freedoms and instituting multiparty systems, implementing civil freedoms and creating vibrant independent media, hoping that their existence would enhance transparency and informational disclosure, which in turn assists in exposing their indiscretions and ultimately making them accountable.

This paper contends and makes the case that the FEACC was structured, just like much donorfunded and supported centralized ACAs, under the principal-agent framework (see Proclamation No. $\underline{433 / 2005}$, for example.) After the brief introduction of the corruption phenomenon known as state capture, it delves into the actual Ethiopian corruption scourge to ascertain that the corruption scourge engulfing the country could indeed be analyzed using the theory of state capture. It uses a variety of sources to characterize the Ethiopian corruption phenomenon as the highest form of state capture. These include insider information obtained through personal interviews involving some prominent individuals who were high-ranking members (but who are now dissidents) of the current ruling party and revelations made by the same individuals through their writings and interviews they provided to other media outlets dealing with the corrupt decision-making process of the regime. It incorporates research conducted by academicians and experts in the field of corruption and the ruling party's anticorruption initiatives. It also incorporates personal on the ground observations made by the author while visiting the country. It integrates and numerous newspaper accounts to show the unique phenomenon of corruption structure that transpired in a country. The paper also draws upon corruption-related research done by the author and uses the immense amount of information he collected over many years regarding the extent of corruption in the country.

Part II below presents state capture and uses it as the analytical methodology, linking the systemic Ethiopian institutionalized corruption with the theory of state capture. This framework is used to characterize the Ethiopian corruption conundrum as the highest form of state capture. Part III briefly discusses the explicit or implicit methods in which anti-corruption agencies, including the FEACC, are set up. Part IV lays out some testable hypotheses. Part V goes deeper and unpacks the phenomenon of corruption in Ethiopia. Part VI briefly discusses the important roles played by independent media, civil service organizations, etc. in the fight against corruption. The same section shows the captured nature 
Hassan: Corruption, State Capture and the Effectiveness of Anti-Corruption Agency in PostCommunist Ethiopia

of these important supporting cast. The point is that, even if Ethiopia's corruption conundrum happens to be the administrative (traditional) type, any anti-corruption is an effort doomed to fail without the supporting cast. Part VII briefly discusses the FEACC- related corruption and uses top-level officials' pronouncements to show that the FEACC has indeed failed to curb corruption. Part VIII presents the conclusions, implications, and avenues for future research.

\section{Analytical Methodology: State Capture - A Form of Grand Corruption as the cause of the Problem}

Researchers and practitioners recognize the importance of distinguishing between administrative corruption and state capture (see, for example, Hellman and Kauffmann 2000; Pesic 2007; Matei 2007; Matei and Popa 2009), the latter being the most pernicious and intractable type of corruption. Hellman, Jones, and Kaufmann (2000) define administrative corruption, which may range from petty to grand corruption, as "private payments to public officials to distort the prescribed implantation of official rules and policies." More simply, administrative corruption is illegal activity "in which public officials extort or otherwise exploit the private sector for private ends" (Shah, p. 235.) As such, administrative corruption is one observes or encounters in almost all countries, save post-communist (transition) countries. It deals with the extent to which the bribe payer uses the existing laws, rules, and regulations to tip the balance in his favor. Administrative corruption largely deals with daily administrative issues and takes place at the implementation level of the bureaucracy. As such, it is episodic/spontaneous rather than being endemic. It is intermittent when it comes to the high level of corruption committed by one or more high-level rogue officials.

By contrast, the most insidious, systematic, organized and predatory form of corruption that manifested itself mainly in transition (formerly socialist) countries is state capture. Hellman, Jones, and Kaufmann (2000) define state capture as one that is "shaping the formation of the basic rules of the game (laws, rules, decrees, and regulations) through illicit and non-transparent private payments to public officials." State capture is a phenomenon in which powerful groups exert their corrupt and undue influence to shape the institutions and policies, laws and regulations of the state for their benefit rather than for the public good. Unlike administrative corruption, state capture is a highly institutionalized and systemic type of corruption. A captured state's institutions are thus incapable of serving the nation's and the public's interest.

State capture could arise and be practiced in several ways: it could result from powerful individuals, groups or firms using both non-transparent provisions as well as legitimate and transparent channels to deny competing groups have access to state officials and resources. It may manifest itself through the twisting of the rules of the game for the benefit of a certain group. It could also arise from the exploitation of the "unclear boundaries between the political and business interests of state officials" by specific groups and state officials for their mutual benefits at the expense of the society in question (Hellman 1998:3). Broadman and Recanatini (2001), define state capture as one, which is a "particularly harmful form of corruption consisting in the ability of firms to subvert the entire political process to ensure that policies and regulations favorable to their business interests are implemented."

State capture may differ from country to country, the differences emanating from countryspecific contexts, be they institutional, cultural and socio-political standards. In some countries, state capture could be seen as a variant of a corruptive practice known as crony capitalism in which powerful groups, individuals, and oligarchs shape and manipulate the formation of new policies, that is, the "rules of the game"- to their advantages. The phenomenon could be observed whenever state officials pass 
Hassan: Corruption, State Capture and the Effectiveness of Anti-Corruption Agency in PostCommunist Ethiopia

decrees and legislative votes favoring the organized business groups, oligarchs or powerful individuals. It could also be detected in huge "concentration of economic and political power" and economic inequality arising from self-interested actors gaining and controlling the state and its resources (You and Khagram 2004). The state capture phenomenon could also be realized by the collusive activities of powerful leaders (regional or national), ministers, and legislative and judiciary executives, corporate executives of state institutions/agencies and party-owned companies. In some cases, state capture is a result of weak legal and political institutions, for weak institutions are incapable of countering the capturing efforts of willful organized groups. In some other instances, captors purposely weaken the country's legal and political institutions so that they would be susceptible to capture and exploitation. It manifests itself in the stripping of public assets by some powerful individuals or organized groups who use the "privatization" process to benefit themselves and the thwarting of economic reforms (Demissie n.d.). In some instances, state capture could be observed when organized groups or clans clandestinely create a "state within a state" (Pesic 2007; Wedel 2001, 2003), a "Shadow State" (Bayart et al. 19993), or "parallel state" (Briscoe, 2008.) In so doing, they influence the state structures, including the judiciary, the security apparatus, the military, and even the media. In some countries, where state capture has occurred, the line between what is private and what is public, what is official and nonofficial, and what is state and what is market are blurred (Philp et al. $\underline{\text { n.d.) }}$.) Thus, under state capture, a country's laws, regulations, legalities, and ultimately its institutions are part of corrupt transactions. As Kaufmann (2012) explains, the captors may include any powerful individuals, an autocrat's family members, ethnically organized groups, the military, powerful firms, or a combination of them who try to exert undue influence, or capture the "rules of the game."

In some countries such as Ethiopia (Hassan 2013), and to a limited extent, countries such as Uganda, Rwanda, and Egypt (Hassan Feb 09, 2016), the entire political, economic, legal and military structures are under the control of powerful cliques or ethnically organized groups (Vestal, 117-212). Corruption of this type is pernicious because of these same organized groups, in collaboration with owners of powerful firms and oligarchs happen to dominate the vital sectors of all institutions (economic, social, legal and military). In some cases, as manifested in countries such as Russia in the 1990s and Ethiopia, the practice of capture is highly organized and predatory. In these countries, captors use, among other things, violence and intimidation (U.S. State Dept. 2015 Annual Report and various annual issues.) They create their monopolies (oligarchies) and cartels to monopolize the vital sectors of the economic system while at the same time disabling the ongoing market reforms. In short, this kind of corruption resembles a modern version of organized crime.

\section{Ethiopian Anticorruption Agency (FEACC): A Generic ACA for a Non-generic Corruption}

\footnotetext{
${ }^{3}$ Bayart et al. (1999: xxii, 15, 16, 25, 26, 101, 109), illustrate the 'criminal state' and 'shadow state" as one whose top leaders: (1) benefit from the privatization process and foreign aid; (2) use legitimate state organs, such as the army, the police and the national security agencies, to commit state-led violence and coercions; (3) use government fiscal allocations, customs and tax policies and the informal sector of the economy to benefit themselves and their cronies; (4) launder money using the import-export schemes; (5) attack their political opponents using the so-called "anticorruption crusade" as well as the courts; and even (6) manipulate national data and statistics. These are also characteristics of a "predatory state" as theorized by Bavister-Gould (2011). In a predatory state, leaders "accumulate and deploy high degree of concentration of power and economic discretion" with the intent to keep "power through a combination of ruthless coercion and material inducement" (BavisterGould, 2011:2).
} 
Hassan: Corruption, State Capture and the Effectiveness of Anti-Corruption Agency in PostCommunist Ethiopia

\section{Phenomenon}

The use of the principal-agent theory in establishing and using an anti-corruption agency is fraught with two major difficulties: definitional (semantic) and pragmatic. In regards to the semantic issue, even though several reputable organizations have readily made available "working" definitions of corruption from which anti-corruption agencies emanate, they rarely are capable of encapsulating the systemic corruption scourge engulfing a particular country. Consider, for example, the definitions of corruption provided by the four major donor agencies and Transparency International. The World Bank defines corruption as "the abuse of public office for private gain." The UNDP defines it as "the misuse of public power, office or authority for private benefit - through bribery, extortion, influence peddling, nepotism, fraud, speed money or embezzlement." The OECD describes corruption being an "active or passive misuse of the powers of public officials (appointed or elected) for private financial or other benefits;" and Transparency International defines it as "the misuse of entrusted power for private gain." The above taxonomies, at best, may be capable of characterizing traditional patterns of corruption known as administrative corruption consuming a country (Hellman et al. 2000; Matei and Popa n.d.). They may help us characterize a corruptive state infiltrated by organized groups. They may explain corruption being as a deviation from a set of bureaucratic rules. As we show in this paper, these taxonomies and their accompanying strategies miserably fail when the corruption conundrum afflicting the country happens to be a "state-engineered" system of political corruption known as state capture.

The PA/PAC models assume the agents-whomever they may be- are the deviants or perverted individuals who exploit the existence of asymmetric information to their advantage while principals are clean or principled. Reducing corruption using the PA/PAC models is straightforward: [raise] the probability of detection and punishment or increasing the severity of punishment..." Khan 2008:32.) The flaw with the PA/PAC theory and hence, by extension an anti-corruption agency is that of the unidentifiable nature of participants of corruption if both the principal and agent happen to be engaged in corruption.

These models are also ineffective if the corruption phenomenon is systemic under which corruption is institutionalized as in the case of Ethiopia (Addis Standard June 21, 2013.) Ethiopia's crafty institutionalized corruption fits Darden's (2002:33) theory of top-down corruption "[serving] as a means through which state leaders buy compliance from subordinate officials - i.e., an informal contract - and also provides the basis for control through systematic blackmail and the threat of selective enforcement of the law." As we argue below, in the case of Ethiopia, the "principals" not only are themselves corrupt (i.e., unprincipled) but also entice others to engage in corruption. As a result, corruption has spread throughout the country, to the extent that it has affected the foundation and culture of the country (Hassan Feb 18, 2016; 2008; Kebede 2013.) Corrupt officials also intentionally create circumstances so that lower-level officials could also engage in corruption. Under such circumstances, the principals are the main cause of corruption. As Khan 2008:33) emphatically notes:

When the natural predilection of the vast majority of the bureaucracy is to favor their friends or relatives, it requires an iron will to enforce the rules. A corrupt leadership is far less likely to exhibit such resolve than an honest one, if for no other reason than the fact that a dishonest leadership has already demonstrated that its strength of character is lacking.

In regards to the pragmatic issue, both researchers and practitioners conduct corruption surveys to ascertain the extent of corruption found in a country. It is under the same principal-agent theory that the World Bank has been commissioning Ethiopian-related corruption surveys. The first of this was the 1998 outline involving corruption-prone government sectors that the Bank's eight-person mission identified. The same report indicates that the Government of Ethiopia (GoE) has agreed to implement an anti-corruption undertaking as outlined by the Bank. This was followed by APAP's publication of the 
Hassan: Corruption, State Capture and the Effectiveness of Anti-Corruption Agency in PostCommunist Ethiopia

first relatively comprehensive corruption survey in 2001. A Tanzanian-based U.S. company, Kilimanjaro International Corporation (KIC), conducted a second World Bank partially financed corruption survey. The survey was conducted in collaboration with the FEACC, portions of which was released in April 2012. The third one was a 2012 diagnostic survey that was published by a group of 11 researchers, from the United Kingdom, South Africa, and the United States, led by Janelle Plummer of the World Bank. The FEACC, in collaboration with the Bank and other donor countries, has also conducted (and released in 2014) a corruption perception survey involving foreign investors in the Country. Other agencies that conducted Ethiopian related surveys include Freedom House (2007 and 2011) and Transparency International (TI). Independent researchers such as Mengistu and Vogel (2009) and Mengistu, Hassan and Teclu (2013) have also conducted their surveys. These surveys were all geared towards gathering information about the extent of corruption in the country and assist the anti-corruption agency in its fight against corruption.

The corruption above surveys share important common characteristics: For one, they are designed to deal with an administrative type of corruption, and not that of state capture. Secondly, the surveys were conducted either in collaboration of the FEACC and with the blessing (permission) of the ruling party. No serious corruption survey is conducted without the permission of the government. Thirdly, they all indicate corruption being a serious issue for the country. Lastly, they all acknowledge the importance of stakeholders' participation in the fight against corruption and hence urge the ruling party to create an environment in which an independent media and civil society organizations and their foreign counterparts would participate in the fight against corruption. The recommendations remained unheeded, unfortunately.

The paper makes the following contributions to the field of corruption and anti-corruption agencies: By drawing insights into the structure, pattern, depth, and complexity as well as actual practices inherent within the Ethiopian corruption conundrum, we unpack the phenomenon of corruption in the country. Our study builds on the conceptualization and analytical framework for understanding the observable corruption phenomenon in Ethiopia, making clear distinctions between administrative/bureaucratic corruption (on which anti-corruption agencies largely are based) and the highest form of corruption known as state capture. We argue that the Ethiopian corruption phenomenon is an extreme version of systemic corruption that can be subsumed under state capture. Such a conceptualization renders the readily made anti-corruption typologies mentioned above to be incapable of capturing the manifestations of the Ethiopian corruption conundrum. Our first contention, therefore, is that the FEACC is a generic anti-corruption agency (an institutional approach to curbing corruption, i.e., principal-agent theory.) Our second contention is that the FEACC miserably failed in curtailing corruption. Our third contention is that the FEACC failed to curb corruption either because of a mischaracterization of the corruption phenomenon in Ethiopia or the use of a generic corruption agency for combating a non-generic corruption, or both. Our last contention is that the Ethiopian regime established the FEACC not only to reduce public anger about the rampant corruption but also to neutralize (and attack) the regime's political opponents (Freedom House 2007) while at the same time placating international donors. We lay out some testable hypotheses to ascertain out contentions.

\section{Hypotheses: -Failure to Grasp the Systemic Nature of Corruption}

The FEACC was established with the push and financial support of multilateral institutions such as the World Bank (World Bank 1998) ${ }^{4}$ and other bilateral donor aid agencies (see, for example, Tamyalew

\footnotetext{
${ }^{4}$ It is not clear why the World Bank continues to push for and supports establishing ACAs in countries where
} 
Hassan: Corruption, State Capture and the Effectiveness of Anti-Corruption Agency in PostCommunist Ethiopia

2010:25, footnote 15, $)^{5}$ with the presumption that corruption in Ethiopia is getting worse and intervention was necessary. A specialized, independent and freestanding ACA, set up under the PA/PAC system could therefore be used to tackle the country's corruption problem (Hanna et al. 2011; Carr 2008; Persson, Rothstein \& Teorell 2013; Mungiu-Pippidi 2013; Bauhr \& Nasiritousi 2011; Rothstein 2011; Marquette, Pavarala \& Malik 2014; Marquette \& Caryn Peiffer 2015). However, its effectiveness hinges on several conditions that we like to present some of them as hypotheses/propositions:

Hypothesis/Proposition I: There exist "principled principals" in Ethiopia who genuinely oppose corruption and who possess the required political will to enforce the rule of law and punish the indiscretions of corrupt bureaucrats (agents). The "benevolent" principals are genuinely concerned about the adverse effects of corruption. The principals are clean, transparent, honest, accountable, and acting on behalf of their citizens. Hence, if assisted by a specialized anti-corruption agency, the principals and the political system in place can make corrupt representatives and civil servants accountable to the principals, the political system in place and the voters. If so, an anti-corruption agency, modeled under the principal-agent or principal-agent-client theory would serve as a tool in combating and reducing corruption.

Hypothesis/Proposition II: The Ethiopian corruption phenomenon is largely administrative (bureaucratic) and episodic, but not systemic/pervasive. Corruption is largely committed by some deviant and mostly low-level officials and bureaucrats. Under non-systemic and non-pervasive corruption, the principals and the agents are distinguishable/identifiable. Under such a system, one is likely to identify/find honest and committed principals who act in the best interest of the public and are accountable to the public and risk-averse. This implies that it is possible to incentivize the system by rewarding or punishing agents using the anti-corruption agency. If in case agents happen to act to maximize their private gains by engaging in corruption, all that is needed is change the incentive structure. Under this scenario in which the FEACC is set up to operate, at least some members of the law enforcement agencies (the judiciary, anti-corruption investigators, prosecutors, and the police) are relatively clean from corruption and hence are willing and able to any corrupt and criminal acts and genuinely implement anti-corruption reforms.

Hypothesis III: The corruption phenomenon in Ethiopia is non-institutionalized, non-state engineered, non-deliberate, non-orchestrated, not driven by top-level officials, and non-collusive at the top of the government. That is, the seeds of corruption are unsown by the top echelons of the ruling party. Therefore, largely the agents, not the principals, commit corruption.

Hypothesis IV: Stakeholders and anti-corruption supporting cast- hypothesis: There exist good and strong institutions (such as an effective judicial system, auditing authorities, un-captured parliament), a well-functioning and independent (un-captured) media with minimal censorship. There exist independent civil society organizations and private citizens; there are governance structures such as an independent Ombudsman encouraging and protecting whistleblowers- all individually or

corruption known to be systemic. Such a push and support is even more puzzling especially after the Bank being advised not to do so by its own staff members and researchers. For example, according to Fjeldstad and Isaksen (World Bank 2008:12), this advice was given to the Bank by two of its staff members, namely, Huther \& Shah as early as 2000. The two staffers had noted that not only it would not make any sense for the Bank to spend its resources in establishing "special anti-corruption investigative units in highly corrupt societies" [for such] units are likely to become corrupt themselves" but it would also be a waste of resources.

5 This 1999 World Bank Infobriefs note indicate that the Bank was indeed financially supporting and pushing for Ethiopia, Uganda, Tanzania, Malawi and Benin to establish anti-corruption agencies. 
Hassan: Corruption, State Capture and the Effectiveness of Anti-Corruption Agency in PostCommunist Ethiopia

collaboratively being able to assist the fight against corruption. The FEACC can garner collaborative assistance and support from civil society organizations, the media, concerned citizens, and advocates of good governance, and other relevant government departments/agencies. The FEACC is capable of fending off retaliation from corrupt officials who are under investigation.

Hypothesis V: Motive of Establishing the FEACC: The FEACC was established as part of a genuine government reform mechanism and to genuinely fight corruption and not to satisfy (or placate) external forces such as the World Bank and other donor nations, and not as a tool to incapacitate/neutralize the ruling party's or the Prime Minister's political opponents. The ruling party does not promote high-level corrupt officials and reappoint them to different official positions (Muhumuza (2016: 69.)

Hypothesis VI: Effectiveness of FEACC (Rose-Ackerman 2004; Think Tank Fund, October 15, 2015:3): The FEACC was set up in such a way that powerful politicians would not capture the agency itself.

Corollary 1 to Hypothesis VI: Members of the FEACC are competent, independent, and not members of the ruling political party.

Corollary 2 to Hypothesis VI: he FEACC is entrusted with the necessary and unambiguous investigative and prosecutorial powers and is mandated to punish all unscrupulous agents, including high-level officials.

Corollary 3 to Hypothesis VI: Anti-corruption board members (at least those at high-level positions) are neutral and not members of the ruling party, thereby ensuring the credibility of both the process and outcome of the investigation of any corruption allegations.

Corollary 4 to Hypothesis VI: The FEACC is designed as part of the governance reform and economic development strategies.

Corollary 5 to Hypotheses IV \& VI: The Ethiopian political environment is participative and hence allows and enables all stakeholders (private media, CSOs, NGOs, the business community, religious groups and the citizens at large) in the fight against corruption (Kpundeh 2000.)

Corollary 6 to Hypothesis VI: Personnel heading the FEACC are selected through a transparent process that ensures their independence, impartiality, neutrality, integrity, apolitical stance and competence.

Corollary 7 to Hypothesis VI: The FEACC was and continues to be furnished with adequate resources and staff to do its jobs. The FEACC hires personnel through open competition (perhaps with relevant experience in corruption-prone fields and trained properly) and not based on their political allegiance and affiliation. The FEACC commissioners and staff members themselves are not vulnerable to manipulation and corruption, such as being removed by powerful officials without due process and illegally. The anti-corruption agency is independent, the principals being unable to capture it. The FEACC and staff members are incorruptible. The commission is staffed with competent personnel.

Hypothesis VII: The FEACC is not hurriedly established, as is customary for African states.

Alternative Hypothesis: None of the above is true.

\section{Unpacking the Non-ordinary State of Corruption in Ethiopia}

The Ethiopian Peoples' Revolutionary Democratic Front (EPRDF), an umbrella organization composed of ethnic-based regional organizations under the control of the Tigray People's Liberation Front (TPLF'), came to power in 1991, after violently toppling the military junta, known as the Dergue. The EPRDF is led by the same TPLF whose members entertained the state they purport to represent, Tigray, to secede from Ethiopia (Young 2006:99-100; Berhe 2008: 191-193; McCracken 2004; Milkias 2001:3.) In toppling

\footnotetext{
${ }^{6}$ The TPLF purports to represent the people of Tigray state, which accounts only for about $6 \%$ of the Ethiopian population.
} 
Hassan: Corruption, State Capture and the Effectiveness of Anti-Corruption Agency in PostCommunist Ethiopia

the Dergue, the TPLF collaborated with its counterpart, the Eritrean Peoples'Liberation Front (EPLF). It obtained assistance from many of the Middle Eastern nations, which happen to be Ethiopia's traditional arch enemies. The TPLF not only aided and abetted the dismembering of Ethiopia by encouraging Eritrea to secede and making Ethiopia a landlocked country, but its leaders also harbor no shame in profusing, with bravado speaking, about Eritrea's secession from the Ethiopia they now rule. As a Front, the TPLF used outright deceptions, robbery, theft, and brutal violence as its main tools of enriching itself (BBC March 6, 2010; wikileaks.org; Hassan 2013 (a); Berhe 2008; Genocide Watch 25 February 2004; Human Rights Watch March 23, 2005; June 6, 2016; Addis Standard October, 2016; New York Times June 18, 2007.) The TPLF is the same organization that the Global Terrorism Database had listed as a perpetrator of terrorism when the party was a Front.

Using its financial umbrella organization that it established in 1978, namely the Relief Society of Tigray (REST), the TPLF cruelly converted aid money into cash and military weapons (Vestal 1999: 174179; BBC 3 March 2010; Daily Mail 18 March 2010; The Guardian, March 17, 2010; Hassan 2013 (a)). As a secessionist Front, the TPLF is known to have looted Ethiopian assets using various means. They included robbing banks and breaking their safe deposits; ransacking publicly owned enterprises and cooperatives; confiscating privately owned companies; and extorting money and tax from defenseless citizens (McCracken 2004; Anonymous, 206: 112; Hassan 2013(b)). On their way to the capital, Addis Ababa, from their bases in Tigray, the TPLF leaders confiscated any liquid or easily moveable assets they could lay their hands on (Vaughan et al. 2011). Once in power, TPLF's corrupt acts became licitly rapacious, to the extent that the acts involved brazen lootings and hoardings (Young 1997; Vestal 1999:174-75; Negash, 1996:15; Mersha 2010; McCracken 2004). $)^{7}$ As confirmed by several TPLF's former echelons, who later become dissidents, TPLF's leaders used the confiscated assets as seed money to establish political-party-owned companies across a range of sectors. Many of these party-owned companies are now subsidiaries of the supra conglomerate known as the Endowment Fund for the Rehabilitation of Tigray or EFFORT (Vaughn and Gebremichael 2011; WikiLeaks September 5, 2011; Abbink \& Hagmann 2013; Addis Standard January 16, 2017; Hassan 2013 (b)). Various sources in the 1990 s had indicated that "EFFORT started its business ventures with a lofty investment volume of about 2.7 billion birr" (just under the US \$1 billion with then about 9 birr per \$1 U.S.)

As soon as the TPLF devised a mechanism to divide the country's political system along ethnic and clan-based enclaves, it quickly and skillfully moved into creating several surrogate or satellite parties and ethnic-based organizations. ${ }^{8}$ Using its loyal followers, a large portion of whom were former prisoners of war, the TPLF installed a highly successful clientelistic and patronage system (Chanie 2007),

\footnotetext{
7 The TPLF created sisterly political NGOs (collaborative members of the cartel) that could be considered, as "members of crime" (Charap and Harm, 1999:14) owned by its satellite/surrogate ethnic-based coalition partners (Mulataa 2010). These are Endeavour of ANDM (Amhara), Tumsa Endowment (formerly Dinsho) of OPDO (Oromiya), and Wendo Group of Southern People Development Association (SPDA). Several reports indicate a diminishing market share of the latter three due to several factors. They include corruption and lack of competitiveness, stiff competition from privately owned companies, and most importantly, increased dominance of the supra-national EFFORT and its subsidiaries, which continue to enjoy enormous patronage (Abbink \& Hagmann, 2013; Bosna 2014; Negash 2013; Kebede 2013.) In its 2007 report, the World Bank states: “...In some instances, direct competition between endowment and private firms has resulted in the closure and exit of the private firm...." Also see, allafrica.com (2007), and Vaughan and Gebremichael (2011). 8 The number registered political parties was said to have mushroomed to 92, the National Electoral Board of Ethiopia's one time list showing 79 country-wide and regional registered parties.
} 
Hassan: Corruption, State Capture and the Effectiveness of Anti-Corruption Agency in PostCommunist Ethiopia

buying the same loyalists with appointments to regional high offices and party leadership ${ }^{9}$. This enabled the TPLF and its surrogates to effectively control the country's political apparatus and the vital resources of the country and establish a kleptocratic elite cartel. As a victor, the TPLF felt "entitled to control the lever of power" thereby keeping key political appointments and dismissals under its discretion (Zerai December 10, 2016.) As the dominant front within the coalition, the TPLF has been at the top of the nerve centers of the Ethiopian politico-economic machinery, including the central bank, the military (Chief of Staff of the armed forces), intelligence and security organs, foreign affairs, and key diplomatic positions. As we show in this segment of the paper, it is the same skewed political arrangement that has been the source of institutionalized corruption and consequently rising public anger.

Using the funds obtained criminally as seed money, the Front founded a series of interlocking companies subsumed under EFFORT. TPLF'S EFFORT and MIDROC now control the commanding heights of the Ethiopian economy. EFFORT's intricate system of shares and investments comprise all sectors, a senior party member CEOs and GMs are each of which (Abbink and Hagmann, 2013). The tactics employed include insider deals (wikileaks.com; Hailu 2005:38-51), steering government contracts to party-owned companies, patronage, tax evasion, outright lootings and a variety of other unscrupulous tactics which included vindictively forcing private companies out of business (Ofcansky and Shinn 2004:138; Uliah 16, January 2017).

EFFORT's deep reaches now include all strategic economic sectors of the Ethiopian economy: Agriculture, manufacturing, imports-exports, construction and urban land developing, insurance, mining, and exploration, banking and microfinance, pharmaceuticals, transportation, printing and publishing, broadcasting and consultancy. These companies are all managed by senior leaders and political cadres. ${ }^{10}$ Many blame these same "endowed" conglomerates as ones who plunder the country via various means, including enjoying unlawful access to loans (without sufficient or proper collateral) and defaulting on the loans and consequently causing one of the country's banks to collapse (Mersha 2008; Gelaw 2010.) They considered as being menaces to the Ethiopian people and privately owned enterprises (World Bank 2009) who use the government as their asset for profiteering purposes and as a "merchants of death" (Debalke 2017).

The fact that corruption in Ethiopia has penetrated all spheres of life is documented by several researchers, practitioners, and organizations. These include the works of Young 1997; Vestal 1999; Mengistu, Hassan and Teklu 2013; Ayalew 2005; Assefa 2004; Chanie 2007; Arriola 2011; Hassan 2013(a), 2013(b)); Abegaz 2011; Anonymous 2006; Hailu 2005; Negash 1996; Regassa 2003. Donors, anti-corruption agencies, and other global organizations have lodged similar complaints as well. Examples include World Bank 2008, 2012; Global Financial Integrity 2015; Human Rights Watch 2009; Oakland Institute 2015; UNECA 2016; UNDP 2011; WikiLeaks 2011; International Crisis Group 2009; Global Financial Integrity 2011; U.S. Department of State 2011; Transparency International 2008; Tamyalew 2010; and Mezmur and Koen 2011.)

\footnotetext{
${ }^{9}$ The NATO Parliamentary Delegation that visited Ethiopia in 2010 acknowledged the existence of two business communities: insiders and outsiders, the former being able to "flourish because of connections to the ruling elite."

10 The ruling party's leaders are also CEOs and GMs of the cash cow state-owned enterprises (SOEs) such as the corruption infested Ethio-telecom and Ethiopian Electric Co. as well as Ethiopian Airlines (International Crisis Group 2009:16; Milkias, 2001; World Bank, 2012; Addis Fortune, January, 26, 2014 ). Even at ministries where top members of the TPLF do not seem to be at the helm, the second in command members weld real powers at all government and non-government organizations here is an older version of a list of companies subsumed under EFFORT. The "endowed" company and its numerous offshoot small-size companies have been growing every year.
} 
Hassan: Corruption, State Capture and the Effectiveness of Anti-Corruption Agency in PostCommunist Ethiopia

As a socialist regime, the Dergue had repressed not only market forces but also nationalized all privately owned enterprises and rural and urban lands. Ethiopia, therefore, went through a postcommunist transition under the EPRDF and hence was one of the "transition countries" that emerged from the ravages of the socialist and authoritarian regime. Just like many post-communist countries, the "transition" and orientation from state planning to a "market system" created opportunities for organized groups to engage in high-level of corruption. Akin to its post-communist counterparts, Ethiopia experienced the misfortune of yet another authoritarian regime, the TPLF/EPRDF, which shaped the rules of the game resulting in systemic corruption. Just like Russia, Ukraine and many members of the old Soviet Bloc (Johnston 2005), the EPRDF formed collusive networks comprising business interests and high-powered politicians (Abegaz 2011; Vaughan and Gebremichael 2011; Hassan 2013 (b)). As observed in many transition countries which included Russia (Goldman 2003), the "privatization" process was plagued with transfers of state-owned enterprises to powerful individuals and party-owned parastatals via tender manipulations (Anonymous 2006: 17; Vestal 1999:174; Demissie n.d.; Hailu 2005: 38-6411; Regassa 2003: 51-53; U.S. Embassy 200212; U.S. State Department Annual Report 2005; World Bank 2012: 99.) As it took place in Russia (Black, et al. 1999) and other transition countries, IMF-pushed privatization led to massive official self-dealings and expropriations (Milkias, 2001: 13; Kebede 2013; Demissie ‥ d.) The IMF, in collaboration with the World Bank, ${ }^{13}$ embraced and even pushed quick privatization without the ingredients being in place to make privatization successful (Guriev and Megginson, 1999; Regassa 2003; Demissie n.d.) Privatization in Ethiopia was pushed despite its early known pitfalls (McCarthy and Puffer 1995), in the presence of widespread institutional weaknesses (Rutland n.d.; Nellis 2005) and even the ruling party's resistance to privatization. The IMF is also known to have praised the late Prime Minister Zenawi for his privatization plans despite the fact that privatization had already led to a number of state-owned enterprises (SOEs) being taken over by the TPLF and its affiliates such as MIDROC (Vestal, 1999: 175; Young, 1997:86; Milkias 2001: 13; Mersha 2008.) The Ethiopian cartel of today also fits the one Johnston (2005:89) describes as an "interlocking

\footnotetext{
${ }^{11}$ In his Master's thesis that involved surveys, Hishe Hailu (2005:pp.38-39) documents several problems with the ways in which the SOEs were "privatized." They included: (a) extreme secrecy; (b) privatizing the SOEs without putting in place proper conditions that would have made privatization to be effective (in particular, the presence of the legal and institutional frameworks which would guarantee transparency, proper valuation, competition, impact assessments of the privatized firms, for example, loss of revenue for the government, loss of jobs to workers, the potential for price hikes after privatization, etc.; (c) mishandlings with aching rigmarole operations, delays, haphazardness, etc. some of them not getting their decision fate after seven years of applications; (d) selling the SOEs to individuals who didn't have sufficient collateral; (e) allowing individuals to buy the SOEs who could turn around and borrow funds from government owned banks.

${ }^{12}$ For example, in this same report, the embassy had stated (which was later deleted): "Privatization, like other government tenders, is subject to corruption. The EPA Board of Directors is made up of government officials and cannot be considered neutral. The decision of what enterprises to schedule for privatization, or whether to remove an enterprise from the schedule, rests with people who have vested interests and manipulate the system to benefit themselves, friends and/or family." Incidentally, the U.S. Embassy criticism was also documented by a well known know blogger of Ethiopundit.

${ }^{13}$ In its 2007 report, the World Bank states: “...In some instances, direct competition between endowment and private firms has resulted in the closure and exit of the private firm...." In several of its country reports, the Bank has noted that party-owned parastatals enjoy preferential access to government contracts, capital, tax breaks, and privileged support in administrative services.
} 
Hassan: Corruption, State Capture and the Effectiveness of Anti-Corruption Agency in PostCommunist Ethiopia

groups of top politicians, business figures, bureaucrats, military and ethnic leaders [who] share corrupt benefits among themselves."

The group in power used various tactics to facilitate its criminal activities. These include: (1) forcefully positioning their political cadres on vital government institutions as "managers, security personnel, customs officials, bankers, accountants, 'judges,' mass organization bosses, ecclesiastical persons, merchants, brokers, contractors, inspectors, peasant handlers and so on" (Ayele n.d.) Controlling vital positions of legislative powers allowed them to limit political competition (Kebede 2013.) These controls enabled them to "win elections" “... through violence, involving intimidation, manipulation, detentions of political opponents and civilians, torture, arbitrary killings, disappearances and political assassinations" (Teshome 2009; Arriola and Lyons 2016; Abbink 2006; International Crisis Group 2009; U.S. Institute of Peace 2007; U.S. State Dept. Annual Report 2013; Freedom House, 2015; Berhanu. n.d.)

They also included a weakening of the nation's institutions (Addis Standard January 7, 2017). Two factors played a role for the weakening of the country's institutions which in turn undermined the integrity of the country's institutions and the government's ability to function properly: (1) EPRDF's desire to gut existing institutions and establish its own by "seeding key state institutions with party ideologues at the expense of those embodying professional standards (wikileaks.org May 16, 2008); and (2) rampant corruption playing a role of a corrosive activity, thereby adding more fuel to the fire. As a result, the weakened and captured institutions became increasingly vulnerable to corruption over time. Most importantly, the weakening and dismantlement of existing institutions created opportunities for the organized elite cartel to go after the country's resources with impunity (Young 1997; Vestal 1999:174-78; McCracken 2004; Assefa Negash 1996; Mersha 2010.) As articulated by Brigaldino (2011), what we observe in Ethiopia is politicians at the top collusively bending or ignoring rules for their mutual benefit and at the expense of the public. Under this scenario, there cannot be a strong and independent anti-corruption institution capable of exposing and punishing high-level corrupt officials.

State capture and high-level corruption in Ethiopia also manifests itself as a clan-based organized elite cartel which ended up controlling the commanding heights of the country's economic sectors (Kebede 2013; Hassan 2008.) As indicated earlier, this has led to the Ethiopian economy being effectively controlled by two economic empires: the TPLF-owned interlocking conglomerate- EFFORT, ${ }^{14}$ and MIDROC (Anonymous 2006: 2; Young 1997; Vestal 1999: 175-78; Vaughan and Tronvoll 2003). ${ }^{15}$ Corruption and state capture do not stop with these two conglomerates as they are aided and abetted by their affiliates, including the rising but highly corrupt and suffocating mammoth military complex known as Metals \& Engineering Corp-MeTEC (Hassan, Feb 18, 2016; Addis Fortune JAN 13, 2013). EFFORT, MeTEC, and MIDROC have extended their tentacles throughout the Ethiopian economy, which

\footnotetext{
14 This author is in possession of a staggering list of EFFORT'S subsidiaries he acquired in the 1990s, even though the same list is somewhat outdated as EFFORT has been elevated to be the supra national since the number of its subsidiaries has increased exponentially.

${ }^{15}$ Vaughan and Tronvoll 2003:20) note that EFFORT and MIDROC, together as an "enormously influential and strategically integrated bloc," dominate "key sectors of the economy" with "political and economic implications of the concentration of such economic power in the hands of bodies effectively controlled by the ruling party" constituting "monopolistic and unfair trading practices."
} 
Hassan: Corruption, State Capture and the Effectiveness of Anti-Corruption Agency in PostCommunist Ethiopia

in turn confers an aura of legitimacy, which includes having business ties with terrorist groups such as alShabab of Somalia activities (Washington post-August 12, 2016.) ${ }^{16}$

State capture in Ethiopia is further evidenced by the staggering amount of capital leaving the country each year (Global Financial Integrity December 15, 2012; The [Ethiopian] Reporter Saturday, 11/3/2012; Addis Fortune Feb 7, 2015; Boyce and Ndikumana October 2012; UNDP 2008.) ${ }^{17}$ It is further indicated by the manipulation of the distribution of state budget funds, such as the diversion of government resources and foreign aid to benefit certain regions and groups (McCracken 2004:186; Chanie 2007; Vestal 1999: 174-79;_Gudina n.d.; Hassan 2013(b)). State capture in the country is attested by the high concentration of economic and political power that is in the hands of a few or a group (Arriola 2011). It is confirmed by the heavy forms of the patron-client system, ${ }^{18}$ crony capitalism, human trafficking (U.S. State Department, various annual reports, such as 2014; 2015) and by drug trafficking (wikileaks.org; 2009; hornaffairs.com, January 18, 2015). It is exposed not only by the ruling party's complete control of the media but also by media-related corruption (Freedom House, April 28, 2015.) State capture is exposed by the constant intimidation and incarceration of journalists who report on corruption. It is explained by the TPLF's production of fake documentaries that create non-existent terrorists; by the skewed stories designed to promote those in power; by the spread of innuendos and false accusations against political or economic rivals.

State capture is further displayed by the late Mr. Zenawi's decision to expropriate the assets of privately owned coffee exports and make way for his party-owned company, namely, Guna Trading Plc. (Hassan April 4, 2009; New York Times March 25, 2009; SMNE, November 4, 2013; BBC, 25 March 2009.) It is witnessed by Mr. Zenawi's threat of cutting the hands (forcefully gathered) owners of private companies, blaming them for the simply vanished 10,000 tons of coffee earmarked for exports. As observed in this Youtube video, the late Zenawi reversed his decision after finding out that his own regional-party-owned company, Guna Trading and his wife (Azeb Mesfin) might have been involved in the disappearance of the "lost" 10,000 tons of coffee. The nature of state captured is affirmed by the fraudulent bidding and procurement process involving World Bank provided funds (Mezlekia March 20, 2012, ) and by the common awards of no-bid contracts (Bankwatch Network 2008; Inter Press Service Feb 6, 2010.)

However, Ethiopia's state capture is unparalleled because nowhere in the world can one observe a complete fusion between a regional ruling party and state institutions, i.e., the Parliament, the judiciary, the police and security forces, the army, and electoral boards (Kebede, 2013; Addis Standard November 25, 2014.) Ethiopian corruption defies common sense because nowhere in the world can one observe a total blending between politics and economics as exhibited by political party

\footnotetext{
16 In its 2007 report, the World Bank states: “...In some instances, direct competition between endowment and private firms has resulted in the closure and exit of the private firm...."

${ }^{17}$ In a meeting he has with business people in mid-2011, even the late Prime Minister Zenawi admitted that \$2 billion was stolen and the funds were extradited to overseas banks. He said he knew who the thieves were and where the funds were deposited. However, as usual, his administration never followed up the case and prosecuted the "thieves," as he used to call them.

${ }^{18}$ Describing the corruption phenomenon in the country, a close friend of the late Prime Minister Zenawi writes: The fact of the matter is that "[ethnic-based] patronage politics or patron-client relationship that has engulfed Ethiopian government bureaucracies at local, regional and federal levels. At local and state levels, connections are forged via loyalty to the ruling party or vial ethnic intermediary roles in order to garner personal gains." (Araia May, 13, 2013)
} 
Hassan: Corruption, State Capture and the Effectiveness of Anti-Corruption Agency in PostCommunist Ethiopia

owned "endowed" conglomerates dominating the vital economic sectors of a country, to the extent of the party and the state being indistinguishable from each other (Hassan February 18, 2016.) No other country in the world is enduring a highly orchestrated and organized malfeasance as manifested by para-NGO EFFORT, which is effectively owned by top-level national political leaders (Addis Standard January 16, 2017; IPS June 16, 2013.) In no other country can one observe a welding between a single ethnic controlled military complex, namely, the highly inept, corrupt, and nepotistic, MeTEC and the state (Anteneh, 2014:56-57; ethiopiaobserver.com July 3rd, 2017; Africaninteligene.com July 21, 2017; The Indian Ocean Newsletter July, 21, 2017; Addis Fortune January 13, 2013.) In no other parts of the world has been a ruling party involved in institutional subversion and making blackmailing and corruption a part of a ruling party doctrine and ultimately the country's culture. Only in Ethiopia have political-party-owned shell companies morphed into behemoths of a country's economic sectors. Only in Ethiopia can one observe high-ranking political cadres multiplying their incomes as heads of "endowed" corporations (political NGOs) they effectively own while at the same time funneling state funds towards these same corporations for 26 years and counting (Anonymous, 2006: 26), all in violation of the country's law. No country in the world (other than Ethiopia) is ruled, for more than a quarter century by a separatist rebel Front that proudly robbed its banks, looted its properties, dismantled public projects (such as power -generating and water pumping machines, bread-baking machinery), broke safe deposits of nationally owned bank accounts and hauled them off to its military bases in Tigray state(Ayele 2001; Demissie n.d.)

In no other country can one observe a conscious and relentless effort to unlevel the playing field, the brunt of this being born by private entrepreneurs in the form of elimination efforts by the ruling party (Anonymous, 2006, 129-63.) Nowhere else in the world can we observe creation and continuous support of party-owned monopolies other than in Ethiopia, twenty-six years and counting!

The tactics deployed to eliminate private business rivals are indeed confounding, which revealed themselves as forms: direct and indirect attacks. Some of the direct attacks include: (1) party operatives levying hefty taxes to evict individually-owned entities from strategically located centers (in order to make room for party-owned enterprises and/or ethnically affiliated companies); (2) arresting private entrepreneurs and charging them with corruption and collusion (Anonymous, 2006: 149:158; Hassan, February, 18, 2016); (3) unjustly expropriating the properties of individuals using flimsy accusation such as hoarding (Hassan April 4, 2009); and (4) blocking non-party affiliated potential buyers of SOEs during the privatization process (Demissie n.d.)

The indirect attacks on the privately owned enterprises and entities emanate from unfair advantages given to political-party owned companies. These include, inter alia: (1) access to confidential information in upcoming bid contracts; (2) illegally giving actual contracts to party-affiliated companies; (3) individuals and intentionally excluding private entrepreneurs (Demissie $\underline{n, d}$, ); (4) awarding contracts to companies that did not participate in a bidding process; ${ }^{19}$ (5) providing access to cheap bank loans and debt-write-offs to party-owned companies; (6) providing access to foreign exchange reserves to party-owned "NGOs" (Hassan September 30, 2010; Kebede 2013); (7) abusing the privatization process to favor para-NGOs (Anonymous 2006: 17-18; 123-24; Vestal 1999: 175; Young 1997.) Such egregious nepotistic and corruptive acts committed by the ruling party are just a tip of the iceberg, embodying the traits of the highest form of state capture.

\footnotetext{
19 The ruling party repeatedly awarded no-bid contract to Salini Costruttori - notorious for its participation in a number of opaque deal projects in the country.
} 
Hassan: Corruption, State Capture and the Effectiveness of Anti-Corruption Agency in PostCommunist Ethiopia

The Ethiopian corruption scourge is a stronger form of state capture because it involves an ultimate takeover of a nation by a group purporting to represent a certain minority ethnic group. It amounts to unimpeded control over all sectors of a country's resources and fiscal appropriations and their transfers to a specific region (Vestal, 1999: 175). It includes a carving up of regions and incorporating them into enclaves and territories of a specific ethnic region (McCracken 2004:185, 204). It involves patron-client transactions in which the patrons engage in outright blackmailing and entrapping, that constantly entices clients to engage in corruption (Anonymous 2006; Kebede 2013, Hassan 2013(b)) ${ }^{20}$. It involves electoral violence (Teshome 2009) to the extent that violence and the sham trials and convictions (Allo and Tesfaye 2015) enabling the ruling party to "win" 100\% of parliamentary seats (Arriola et al. 2016). Ethiopia's high-level corruption, suppression, and exploitation emanate from a long-standing philosophy: EPRDF's 62-page long manifesto of Revolutionary Democracy (2014 Bertelsmann Stiftung's Transformation Index (BTI) Report on Ethiopia; International Crisis Group's 2009 analysis on Ethiopia; Abbink and Hagmann (2013). It emanates from TPLF's paranoia as a minority ethnic group and its intent and legacy of exclusion (Hassan 2008; Tesfanews Sept. 11, 2012.)

Once the regime realized that the Ethiopian people had enough with maladministration, lack of jobs, nepotism and rampant corruption resulting in mass protests, the government decided to placate the public by echoing one of the major citizens' complaints- corruption - while at the same time reverting to increasingly authoritarian tactics. This was revealed by none other than the government's spokesperson, Getachew Reda, repeatedly blaming rampant corruption being the cause for public anger (Reuters October 9, 2016), while at the same time his security forces were gunning down innocent citizens with impunity (HRW June 15, 2016; The Guardian January 18, 2016; U.S. State Dept. Annual Report, 2017.) As is customary, TPLF's Special Forces engaged in mass arrests, excessive use of lethal weapons against the people (Amnesty International 9 November 2016.) In fact, TPLF/EPRDF's past atrocities include: abductions, "enforced disappearances" "torture and preemptory mass killings" of citizens (U.S. State Dept. Annual Report 2007; 2016; safeguardingheallth.org 2016.)

None of the traditional taxonomies of corruption mentioned earlier encapsulates a corruption phenomenon in which mafia-type criminal networks masquerade themselves as lawful government officials while at the same time sabotaging the state they purport to govern. In no other country is foreign aid used for "underwriting repression" (HRW October 9, 2010), for establishing criminal enterprises, the corrupt group commandeering the state machinery as their pillaging tool (Negash, 1996; Hassan 2013 (a, b)). In no other country has the state become a predator, in which the mafia group, instead of being on the fringes of the legal system, is instead a part of it. Nowhere in the world foreign aid has become a major source of corruption (Hassan 2013 (a, b); (HRW October 9, 2010). Nowhere else in the world is donor aid used as a "political weapon[s] to control the population, punish dissent, and undermine political opponents-both real and perceived" (HRW 2010.) Traditional corruption typologies fail to encapsulate a corruption phenomenon which morphed into "deep state" - a state within a state. This is a corruption conundrum created by ethnic-based criminal groups who used their fighters as the conduits to enrich themselves (Hassan, 2013 (a)).

No political party in the world has accumulated such an immense amounts of wealth (as admitted by Mr. Sibhat Nega, one of the founders of the TPLF and veteran leader of the ruling party), most of which is obtained through obscene corruption and leveraging state resources and unfair trade practices.

20 Entrapping lower-level officials with corruption indicates that, in the Ethiopian case, there may not be substantial goal conflicts between the "principals" and the "agents" and minimal asymmetric Information between them as assumed in the principal-agent framework. 
Hassan: Corruption, State Capture and the Effectiveness of Anti-Corruption Agency in PostCommunist Ethiopia

Mr. Nega once told the Voice America that the TPLF is the wealthiest political party in Africa, if not the world. Mr. Nega's daring acknowledgments cements what the public knows already: the existence of a tremendous amount of political and economic concentration that is in the hands of the TPLF. No political regime in the world has made a mockery of the privatization program that the IMF, the World Bank, and Western nations envisioned and pushed for, and used it to build its economic empire via its corruption-infested para-NGOs (Demissie n.d.; Hassan 2013(b).

To our knowledge, nowhere else in the world can one observe a system in which "the rule of winner-takes-all has reigned, the summit of the state-party to its most modest ranks, official positions, and oligarchical rents [being] mutually reinforcing" (Lefort 2016). Nowhere else in the world has emerged a politico-economic system in which "... economic decision-making and the management of public and para-public enterprises are concentrated in the hands of the same people at the summit of the party-state, free of any control and political counterweight..." In no country, other than Ethiopia's corruption "...has led to the creation of a tentacular (sic) and increasingly voracious and arrogant oligarchy, which has ultimately filtered down to village level" (Lefort 2016). What one observes in Ethiopia, therefore, is a suffocating system in which interlocking Para-NGOs reign supreme. As this 1999 complaint indicates, it did not take long for "[e]rstwhile sandal-clad socialist guerrillas" to strike it riches almost overnight. Truly, these are characteristics of a criminal-syndicalist state (CSIS 1997:26. ${ }^{21}$ )

The analysis provided in this paper show that the TPLF possesses monopolistic political and economic power, which in turn allows it not only allocate goods and services and generate lucrative markets to the businesses that it owns but also make corruption as its modus operandi and as one of its main tools to stay in power. This argument is in line with that of Charap and Harm (1999), in which corruption is a deliberate policy of high-level officials serving "as a hostage mechanism." The dictatorial and predatory state (Hassan Feb 09, 2016) not only fails to prosecute (BTI 2014: 10) those involved in corruption, but it also entices lower-level bureaucrats to engage in corruption (and ambush them later on) thereby creating a highly rent-seeking hierarchy of patron-client relationship. Witness Mr. Junedin Sado, who himself, along with members of his family, was implicated in corruption and terrorism (sic) related issues. Mr. Sado was a former president of Oromia, the biggest and most populous regions of the country, from 28 October 2001 until 6 October 2005 and who had held several high-level positions, including as Minister of Transport and Communication, and Minister of Civil Service. Now a political dissident, Mr. Sado recently "revealed" what we know to be true: the use of corruption as an entrapping and hostage-taking mechanism. ${ }^{22}$ In a rather lengthy interview he gave to the Amharic (and also Oromifa) version of the Voice of America, Mr. Sado said that the government's repeated self-critical appraisals (gimgemas) never delivered any good results in regards to reducing corruption, but instead were used as weapons to attack and purge or dislodge "unwanted" individuals. Like many other observers, Mr. Sado confirmed the use of corruption and anti-corruption for purposes other than for

21 This same Center for Strategic and International Studies (CSIS), describes a criminal-syndicalist state as one which involves "corrupt officials at all levels throughout the government bureaucracy, from minister to tax collector to low-level factotum; businessmen for whom ... Western norms of commerce-are simply obstacles to be overcome in one way or another... [It is one that involves a dangerous mix of criminality, government, and business - with a strong, shared interest in self-enrichment, survival, and power, [that] precludes normal interaction with those outside it."

22 In Charap and Harm (1999:15)'s model, entrapping individuals with corrupt activities serves as both the carrot and the stick used to "minimize the probability of defection" and to strengthens loyalty. The corrupt individual remains loyal to high-ranking corrupt officials in part because they are participants of corruption. 
Hassan: Corruption, State Capture and the Effectiveness of Anti-Corruption Agency in PostCommunist Ethiopia

reducing corruption. They include: (a) for entrapping individuals and ambush them later with corruption charges if and when they refuse to obey higher authorities; and/or to root out officials whose loyalty to the regime is questioned; (b) for attacking individuals perceived to becoming too politically powerful and popular to the extent of being threats to top-level TPLF officials; (c) allaying public anger whenever corrupt official's transgressions become a liability to the ruling party; and (d) to use "'the fight against corruption" as a political strategy of settling internal power struggles (Omer July 27, 2017.23) He further noted that the FEACC is incapable of fighting corruption in part because it lacks authority, resources, and personnel, and in part because corruption involves top-level government officials, which include military generals and the heads of the ruling party executives. The ruling party executives raise the anticorruption rhetoric whenever they realize corruption has reached intolerable conditions and to allay public anger. Mr. Sado's claim regarding the deceptive anti-corruption rhetoric is corroborated by Mr. Lefort (2016), who frequently visits the country, talks to ruling party officials and shares with us his observations. Mr. Lefort writes:

The campaign to 'purify' the state-party of its black sheep, launched with much fanfare in the autumn of 2015 , has been a damp squib. It touched only minor officials, while none of the senior figures - some are notorious for their corrupt practices - was affected, leading the population to conclude that the campaign was nothing but a smokescreen.

The pro-ruling party local newspaper, The [Ethiopian] Reporter, in its Saturday, 25 APRIL 2009 edition likened corruption in Ethiopia as being of a mafia type, and it stated:

The underlying nature of mafia groups everywhere is similar. They are organized and secretive. They obtain wealth, reputation as well as power through illegal means and continuously strive to get more of them. They try to get whatever they want and crush anyone they dislike through intimidation and bribery. They engage in abduction, assault, murder, stealing, and robbery. They stop at nothing to manipulate ordinary citizens and government officials to get whatever they want. If they cannot manipulate them, they will destroy them. They have a convoluted chain of command. Sadly, these same groups continue to stay in power controlling the commanding heights of a nation's economic sectors as well as its political nerve center.

In its December 1, 2012, edition, The Reporter, summarized the frustration as follows:

The laws continue to be broken favoring the rich, the well-connected and those who can afford to pay bribes. The corruption virus has even affected the judicial sector to the extent that it is also engulfing the diplomatic sector of the government.... Justice is getting scarcer by the day in Ethiopia. It has become pointless to complain about government agencies because none of them is responsive to the public's grievances. The problem of dispensing justice is systemic; we find ourselves at a time when corrupt and dictatorial public officials as well as their network of cohorts have taken the upper hand leaving honest, law-abiding and patriotic citizens victims of injustice and feeling sidelined and disenfranchised.

In its April 2, 2012, report, the Reporter describes the situation as if the entire country is infested with a web of corruptive landmines. It called on the government and the public to find experts who would dismantle the explosives before they destroy us all. In its Wednesday, 19 October 2011

\footnotetext{
${ }^{23}$ The BTI 214:10, Annual Report on Ethiopia also state that the ruling party anticorruption drives are "(mostly likely for the benefit of potential foreign investors and donors), but were selective and often appeared politically motivated."
} 
Hassan: Corruption, State Capture and the Effectiveness of Anti-Corruption Agency in PostCommunist Ethiopia

editorial reports, The Reporter likened the Ethiopian corruption conundrum as reaching to a level of organized crime. Also, it stated: "[t]he Auditor General's reports have shown time and again that numerous government institutions are guilty of gross financial and property mismanagement. These reports have not resulted in the slew of indictments..."

Again, a pro-government author, whose work is published on highly pro-TPLF webpage writes:

Another major façade that the Government of Ethiopia should seriously rethink is the patronage politics or patron-client relationship that has engulfed Ethiopian government bureaucracies at local, regional, and federal levels. At local and state levels, connections are forged via loyalty to the ruling party or via ethnic intermediary roles to garner personal gains. This kind of corruption is fostered in a patron-client relationship, and it is in this networking that the rent-seekers or the self-interested privilege-seeking officials flourish... The corrupt rent-seeking officials have neither contrition nor remorse in stealing money from the public purse, and by their toxic activity they have, ensued cultural fragmentation, and they could best be defined as predatory officials.... (Araia May 13, 2013.)

Under such a system, corruption is endemic rather than being incidental. It is endogenous, contrary to the system in which the FEACC is established, i.e., corruption being an agency problem in which lower-level bureaucrats 'pervert the sensible rules' that society or the benevolent leader has put in place.

Despite the unparalleled nature of the TPLF/EPRDF's corruptive activities, we believe the Ethiopian corruptive structures presented above largely shares characteristics of state capture. These include, among other things, passing new laws and regulations designed to benefit a certain group or region; exploitation of weakened institutions; using the privatization for self-dealing ${ }^{24}$ and to transfer publicly owned assets to well-connected individuals. They comprise, as reported in the pro-government bi-weekly local paper, spectacular personal wealth accumulations, whether through embezzlement or other dishonest means. They include acquiring the cream of Ethiopia's resources and assets resulting in the rise of two oligarchs - EFFORT and $\mathrm{MIDROC}^{25}$ and, perhaps playing a contributing factor in the rise of income discrepancies (Gebre-Salssie 2013.)

\section{The Importance of Independent Judiciary, Media, and CSOs in Fighting Corruption and ACAs}

The success of an anti-corruption agency depends on its ability to create strong coalitions with those whose goals and values are similar to it. These include, in addition to the judiciary and law enforcement government agencies, the media, civil society organizations (CSOs) and even donors. A free, independent and vibrant media plays important roles in exposing corruption (see, for example,

\footnotetext{
${ }^{24}$ Some of the alleged tactics that the TPLF cadres deployed include, inter alia: (a) opening (illegally) sealed bids prior and revealing bids to friendly competitors; (b) re-tendering publicly announced auctions bids of SOEs and waiting until their friends come up with the funds to buy them; (c) inflating expenditures of the yet-to-beprivatized SOEs in order to scare honest potential buyers while at the same time preparing the ground work for their cronies; (d) selling the SOEs below market price to their cronies and party-owned entities; (e) awarding tenders to either dubious or self-owned companies; creating faked information and presenting the SOEs as being financially weak while at the same time revealing to their cronies that the to-be-auctioned firms actually are wellperforming SOEs; (f) misusing and not reporting the proceeds from selling the SOEs; and ( $g$ ) staffing their cronies in different ministries in order to easily facilitate the transfer of assets and control them as well. These are similar tactics used to steal the Russian SOEs by the insiders.

${ }^{25}$ According to Addis Fortune, MIDROC has at least 32 companies organized under three wings: MIDROC Technology, MIDROC Ethiopia and Derba MIDROC.
} 
Hassan: Corruption, State Capture and the Effectiveness of Anti-Corruption Agency in PostCommunist Ethiopia

World Bank 2000; Arnold \& Lal 2012; Coronel n.d.; Nogara 2009; TI June 13, 2017; Jarso, 2010.) It helps uncover abuses, alert and mobilize the public against corruption, exposes injustices and be a voice for corruption victims and educate the public about corruption. It can even help the

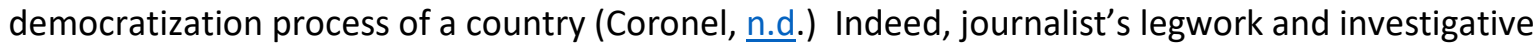
media have led to impeachment and ouster of corrupt presidents around the world, as in the case of former American President Richard Nixon, Philippine President Joseph Estrada, South Korean President Park Geun-Hye. Social media played important roles in ousting authoritarian and corrupt governments in the Middle East, as in the case of Hosni Mubarak of Egypt and Zine al-Abidine Ben Ali of Tunisia. Investigative journalism unearthed a trove of "crime, corruption, and wrongdoing, hidden by secretive offshore companies" as exemplified by the notorious Panama Papers. Most importantly, practitioners acknowledge independent and vibrant media playing crucial roles in assisting anti-corruption agencies (Open Society Foundation, December 2015; World Bank 2010; UNDP 2011).

Instead of allowing and encouraging the media to play its role in the fight against corruption, the EPRDF has been busy in silencing alternative sources of information that is not under its control. In fact, TPLF/EPRDF's assault on the media began as soon it took power (CPJ 1995; 1998. ) $^{26}$ It did so by passing various restrictive laws and regulatory frameworks and using them as its tool to intimidate, harass, exile, imprison and torture journalists (CPJ 1998) for doing their professional work. In the 1990s, the ruling party used its 1992 Press Proclamation, Press Proclamation No. 34/1992, to restrict journalists and citizens' expressions of their grievances and criticisms against the government in dealing with corruption. In the 2000s, the regime somewhat relaxed the clamping down of media freedoms, a little before and during the 2005 election, in particular. The 2005 election debacle led to the notorious 2008 Mass Media and Freedom of Information Proclamation (Press Law). The government used this Press Law to close down many newspapers and magazines, such as the famous Addis Tribune, and arrest and prosecute several journalists (Ross 2010). It used the controversial press law to arrest journalists for reporting about corruption and abuse of power. For example, in 1994, the ruling party imprisoned Daniel Kifle, the then editor of the now-defunct Fendisha magazine. He was arrested "on a defamation charge for an article alleging corruption and for [embezzlement by] Tamrat Layne, then Deputy Prime Minister and Minister of Defense - who was himself [imprisoned for 12 years with corruption charges]. Alemu Lemma of the [defunct] Mebruk magazine was arrested in June 1995 and sentenced to two years' imprisonment for ... defaming a housing official in an article alleging abuse of authority and embezzlement." The government continues to use its anti-defamation law to attack journalists who expose corruption (HRW January 21, 2015.)

Abuses of power just like these were committed by the same ruling party way before the FEACC was established, and it is hard to imagine that donors such as the World Bank did not know the defamation charges. How can anti-corruption efforts succeed if the government persecutes journalists on defamation charges when they report about corruption?

The highly secretive ruling party of Ethiopia is not just like any authoritarian regime that censors the media, which it does (BTI's 2014 Report: 2). It is also a ruling party that squanders the meager resources of a very developing country and buys spyware and hacks into personal computers, including the computers of persons who live outside of the country. The regime in power is one of a few

\footnotetext{
${ }^{26}$ According to CPJ (1998), compared to today's handful of independently owned publications (with tremendous amount of self-censorship being in practice), the country enjoyed "more than 200 independent publications, including over 60 newspapers (mainly weeklies)..."
} 
Hassan: Corruption, State Capture and the Effectiveness of Anti-Corruption Agency in PostCommunist Ethiopia

governments, which use spyware and blocks news outlets and websites (HRW August 13, 2015; Motherboard March 9, 2015.) It constantly uses internet hacking and intercepting technologies to spy on citizens, intimidate government critics and even jams foreign-based radio stations, including donorowned radio stations such as the Voice of America (wikileaks.com), and the German government-owned Deutsche Welle. Accessing compromising information about political and business rivals, electronic eavesdropping and communications security techniques are the daily practice of the ruling party. Notwithstanding the country being one of the least technologically connected countries in the world (Fortune 6 October 2015), Ethiopia is also one of the most censored countries in the world (CPJ, 2015; Washington Post February 9, 2015.)

Not only has the ruling party of Ethiopia been constantly assaulting the free press, to the point of eliminating it (Arriola and Lyons 2016:81), but it has also chosen to clamp down the use of the internet, Skype (Freedom House 2016; BBC 15, June 2012) and social media (BBC 11 July 2016; Daily Nation 12, July 2016), thereby effectively criminalizing the flow of information. The country's current Prime Minister, Hailemariam Desalegn, became a laughing stock after he shamelessly decried social media at the 2016 United Nations annual meeting of world leaders. True to its form, and as has been the case for all transition countries afflicted by state capture, the TPLF/EPRDF controls and uses the press for its propaganda purposes (just like Putin's Russia); to create alternative facts, decode the truth and ultimately influence public opinion. As reported in Ayalew (2005:86-87), every time the (semi) independent media tried to report about corruption, the government-controlled "media plays a counter role... [by providing] substantial airtime to ... promote indirect counter propaganda." If this is not enough, political-party-owned companies harass journalists who report on corruption, charging them for liable. It uses trained recruits to post pro-regime messages on social media outlets, disguising their messages as if they are spontaneous emanating from ordinary people. It uses the media it controls for sinister purposes, such as producing farcical documentaries, as in the case of the so-called "Jihadawi Harakat" and many of its predecessors. How could an anti-corruption agency be successful in an environment in which the government owns nearly all media outlets which in turn allows it to garner influence, censoring stories, and stifle investigations?

Just like an independent and a well-functioning free press, independent civil society organizations (CSOs) can play important roles in identifying corrupt prone areas, raising awareness about the threats caused by corruption, exposing corrupt officials and proposing alternative methods of controlling corruption. CSOs can also proactively assist in monitoring and evaluating the performance of anti-corruption agencies (OECD 2003; UNDP 2011). Unfortunately, instead of recognizing their importance, the ruling party of Ethiopia opted to attack CSOs by arresting their leaders and closing their bank accounts (CPJ (1998; Carnegie Endowment for International Peace May 18, 2017). Participation in an unauthorized demonstration (the authorities do not authorize most opposition demonstrations) may result in 5-15 days of police detention or a fine. Hypocritically enough, the ruling party's $50-60$ percent of the national budget comes from foreign sources while at the same time its CSO Proclamation criminalizes CSOs whose foreign-funding exceeds ten percent of their budget (Hodenfield 8 December 2016.)

Since the regime took power, it reconstituted all civil society organizations under its control, be they humanitarian, pro-democracy, religious, or professional such as teachers and workers' unions (HRW March 24, 2010, January 2003). The ruling party uses it's infamous five persons-into-one networks organizational tactic (imposing state surveillance system) as its main tool of enlisting citizens, this forced conscription getting prominence, particularly after the 2005 election debacle. Such forceful enlisting has resulted in the catapulting of the EPRDF's party-membership from four hundred thousand to seven million strong. 
Hassan: Corruption, State Capture and the Effectiveness of Anti-Corruption Agency in PostCommunist Ethiopia

The Ethiopian regime, which rules by proclamations and passing a multitude of laws, instead of abiding by the rule of law (Abebe 2012), enacted two draconian laws in 2009: the Charities, Society Proclamation (CSO) law, and the Anti-Terrorism Law ${ }^{27}$. It used these laws to arrest arbitrarily, torture and convict journalists, bloggers, political activists, opposition leaders, and civil society leaders (HRW June 16, 2009; Center For International Human Rights of Northwestern University School of Law, November 2009; Aalen \& Tronvoll, 2009).) It used the same laws to implement surveillance on its citizens (Carnage Endowment for Peace, May 18, 2017; HRW March 25, 2014.)

Participation in an unauthorized demonstration results in detention, a fine or both - practices which have been in effect since the early 1990s (U.S. Department State 1994 Annual Report-Ethiopia.) As Solomon Goshu of The Reporter (24 June 2017) noted, the two 2009 draconian laws have led the "hapless" CSOs to be weak and be indistinguishable from the ruling political party. No strong and independent civil society exists in the country (Ayalew 2005; 87.) Citizens are compelled to be members of the ruling party. Should they refuse to comply, punitive measures are taken against those acted independently (Arriola 2011:241), denying them from essential social services such as access to government housing, fertilizers, food aid and even jobs. The government also intentionally creates parallel organizations to incapacitate those the government deems independent of its control.

In one of its executive summary of its study regarding ethics with the Ethiopian Civil Service, the U.N.'s Economic Commission for Africa (1996) sums it up as follows:

[There is] non-involvement of the public and the civil society organisations in anti-corruption activities. Exclusively government departments currently conduct all anti-corruption initiatives. The legislature, the public and other critical civil society organs such as the media, the NGOs, religious organisations, the chamber of commerce are sidelined. There is thus little public understanding or support for what the government is doing.

Such a practice has gotten worse, not better, particularly after the 2005 election debacle and the ruling party's endeavor to conscript over seven million citizens as members of its political party.

The importance of an independent and impartiality of judges, prosecutors, and lawyers for combating corruption is self-evident, as it has been acknowledged by scholars and organizations (see, for example, Srinivasan/OECD n.d.; OECD 16 March 2017; OSCE (Austria) n.d.; Office of the United Nations High Commissioner for Human Rights n.d.; Groop 2013.) Regrettably, not only is undue political interference in judicial affairs commonplace in the country but the judiciary is also itself corrupt (Ofcansky, Shinn 2004; Arriola/Freedom House 2011; Fiseha 2012) to the point of being captured by high-level officials (Hassan, 2013 (b); Kebede 2013.)

The above discussions underscored the fact that even standard anticorruption agencies cannot succeed without the cooperation from an independent judiciary, a free press, and CSOs. Combating and

\footnotetext{
${ }^{27}$ The regime also enacts new laws to facilitate high-level corruption. As this As an example, the ruling party used the 2011 new "law named the Urban Lands Lease Holding Proclamation allows public authorities to nationalize urban lands and to expropriate at will all remaining forms of transferable and inheritable urban private property." The 2005 land law and this law are used for the infamous "land grabbing" process which forcefully evicted indigenous inhabitants and allowed government officials take away land without compensations and those refused to leave their ancestral lands were "either killed or imprisoned (BTI 2014:10.)
} 
Hassan: Corruption, State Capture and the Effectiveness of Anti-Corruption Agency in PostCommunist Ethiopia

curbing corruption requires multi-pronged approaches, the existence, and engagements of the strong and independent judiciary and CSOs and press are each of which.

\section{Post-FEACC Establishment Corruption: Ruling Party Says the FEACC Itself is Corrupt}

a. Introduction

As a practical matter, specialized and "independent" ACAs emerge out of recognition that corruption has become endemic to the extent of being a menace to the country. It may also emerge in response to scandals involving high-ranking officials. Establishing ACAs, preferably alongside with specialized anticorruption courts, become necessary due to a lack of public trust in the criminal justice system. The lack of public trust emanates in part from the inability of courts, the prosecuting authorities and the police to properly prosecute corrupt officials, and in part because these same authorities themselves are perceived to be tainted with corruption. Declaring war on corruption, politicians, therefore, establish ACAs to reduce public anger while at the same time using it to neutralize and attack the regime's political opponents and placate international donors. In the case of post-communist nations, calls for establishing ACAs may emanate from the aid agencies' observation and realizations that powerful groups were grabbing public assets willy-nilly and putting them in their columns while at the same time curbing meaningful reforms.

As it turns out, all the elements mentioned above played a role in the establishment of the FEACC (Tamyalew 2010; Mezmur and Koen 2011; Megiso 2007; Arriola 2011; Belai 2004; Milkias 2001; APRM 2011, World Bank 1998.) In the 1990s, three major culprits led to a boiling point of the corruption nonsense: involvement of high-level officials in gross abuse of power and corruption, the mishandling of privatization and the illegal establishments and enrichments of para-NGOs. The first of it was manifested by the arrest of Tamrat Layne (and eight others) in 1996 who was the deputy prime minister and defense chief. Layne, who was a close associate of the late Prime Minister Zenawi (and one of Mr. Zenawi's "puppets") is known to have embezzled sixteen million dollars and stashed it in Swiss banks. After entrapping him in corruption and appointments he did not deserve, Mr. Zenawi ambushed and humiliated Mr. Layne in front of the entire parliament accusing him of abuse of power and extortion accusations that Mr. Layne accepted (testimony of Mr. Habtamu Alemayehu, a former Member of Parliament). Mr. Layne was later convicted for 18 years in prison and released after 12 years of imprisonment (Swiss Federal Department of Justice and Police-FDIP May 14, 2003; Transparency International Global Corruption Report 2001:71.)

The second cause of public uproar involved the illegal establishment of regional party-owned conglomerates whose board members are high-ranking officials and political party leaders, the embodiment of each of which is EFFORT. As Professor Minga Negash (2010) noted, "... These unique creatures arose in post-conflict Ethiopia after the victors transformed their previous clandestine and illegal businesses into legal, economic entities..." These conglomerates are "often associated with bad management, cronyism, distortion, corruption, non-payment of taxes and credit defaults. They are accused of crowding out of the private sector, interfering in government tender systems and exacerbating inequality by their discriminatory employment practices" (Negash 2010; McCracken, 2004.)

Thirdly, it became glaring clear to all concerned parties, including donor agencies, that the weakened Ethiopian institutions were no match for the highly organized TPLF/EPRDFites, who successfully thwarted the necessary reforms that donor agencies and countries demanded which in turn led donor organizations to doubt TPLF's commitments to market liberalization (Vaughan \& Gebremichael (2011: 20). The recognition of the problem is discerned from the donor's repeated complaints as well. For example, in its 1998, 2007 and 2009 Annual Reports on Ethiopia, the World Bank, 
Hassan: Corruption, State Capture and the Effectiveness of Anti-Corruption Agency in PostCommunist Ethiopia

the regime's top benefactor, stated that the Ethiopian system is highly opaque. ${ }^{28}$ It stated that the ruling party-owned companies possess the commanding heights of the Ethiopian economy enjoying preferential treatments "over private sector companies in regards to government contracts, government controlled credit facilities, import and export licenses, and customs clearances,"(World Bank 1998:7.) As documented in the highly quoted Anonymous (2006:169-175), which was also corroborated by the July 16, 2002, edition of Addis Fortune, heated debates arose among the TPLF leaders. The debates had focused on the: (1) illegality and corrupt nature surrounding the establishment, existence and corrupt nature of para-NGOs, the behemoth that private entrepreneurs detest and dread - EFFORT, in particular; and (2) illegality and misuse of the FEACC for incapacitating Mr. Zenawi's political opponents. Private business groups whose businesses were being dislodged by the para-NGO enterprises have been crying foul to no avail beginning in the early 1990s. According to Addis Fortune, following the complaints of the Chamber of Commerce, the then President of the World Bank had told Mr. Zenawi to divest and privatize the assets of political-party-owned enterprises. According to several sources, the EU and the IMF had made similar requests as well. The complaints emanate from the untenable nature of the TPLF being both a ruling party and its desire to keep the assets it looted from the same country it rules. It was widely speculated that Mr. Zenawi had told the IMF, the World Bank and the EU representatives that the properties that the Front looted and the para-NGO enterprises exclusively belong to the TPLF. The refusal to divest para-NGOs attests the unusual nature of Ethiopian corruption. That is, unlike the conventional wisdom that holds the notion that a "loser class" frustrates the reform and transformation of the post-communist economies in transition, it is the new "winner class" that creates the obstacles to the reform process. This reality is one of the important contributions of a corruption conundrum known as state capture. These realities must have "troubled" the World Bank and other donors to the extent the Bank's 1998 recommendation included establishing the generic anti-corruption agency, which later emerged as the FEACC.

\section{b. FEACC as a Political Tool}

Before the TPLF split of 2001, the government successfully prosecuted only two high-ranking officials for corruption, the prominent one being Mr. Tamrat Layne. Come 2001, in the midst of the TPLF's internal power struggle, Mr. Zenawi and the group allied with him hurriedly established the FEACC $^{29}$. Mr. Zenawi forced lawmakers to illegally amend a provision and pass it overnight so that it could be used to arrest and prosecute his political opponents, whom he labeled as "corrupt and Bonapartists" (Anonymous, 2006: 156.) He used both the newly passed law, the FEACC, in particular, to arrest over 54 high and mostly mid-ranking government officials and businesspersons. A few months later, Mr. Zenawi also illegally removed the FEACC Commissioner, Mrs. Enwey G/Medihin and deputy commissioner Addisu Mengistu, for the simple reason that they attempted to investigate and prosecute high-level members of the ruling party who allied with Mr. Zenawi (such as the then head of National Election Board, Assefa Biru (IRIN 5 May 2003.)) As members of the ruling party, the commissioner and

\footnotetext{
28 Jason McClure, the Bloomberg Reporter from Addis Ababa reported on November 25, 2007 that the then World Bank Ethiopia country Director, Ken Ohashi, admitted that “... the finances of Ethiopia's endowment businesses were opaque and a bank report this year called on policy makers to ensure that endowment firms are managed at arm's-length to the government."

${ }^{29}$ As this 1998 World Bank Report states, the Bank sent a delegation to the country to "... assess the scope and status of Government's efforts to combat corruption, to report its findings..." This further indicates establishing an anticorruption agency was in the works as early as mid-1990s. The FEACC, however, was not established until 2001. This delayed establishment by itself is a sign that Mr. Zenawi's regime might not have been serious in tackling corruption.
} 
Hassan: Corruption, State Capture and the Effectiveness of Anti-Corruption Agency in PostCommunist Ethiopia

deputy commissioner were transferred, in some instances being promoted ${ }^{30}$ (Kebede, 2015; Hassan, 2013(b)) to other government agencies. Mr. Zenawi is also known to have spared high-ranking corrupt officials such as "Bitew Belay and Abate Kisho from prosecution just because they happen to be on his side of the power struggle (IRIN 5 May 2003; Keller 2002: 45). The use of the FEACC as a weapon to attack one's political opponents indicates the farcical nature of the "war against corruption" waged by the late Mr. Zenawi and his collaborators. ${ }^{31}$

Mr. Zenawi is also known to have discarded the Auditor General's damning reports of blatant theft by government officials. Worst of all, Mr. Zenawi illegally dismissed Auditor General Lema Argaw, after the Auditor General presented his report to the Parliament about the huge amount of missing funds at both federal and regional state levels (Freedom House, 2007). In a clear violation of the country's laws, the late Mr. Zenawi arrogantly and lawlessly shouted at Auditor-General Argaw, publicly despising him and his reports and pronouncing that those in power, the regional power brokers, in particular, could even burn the money should they wish do so. No wonder the FEACC staff, in which all of whom are members of the ruling party and are known to go after only mid to low-level officials sporadically care less about high-level corruption (Indian Ocean Newsletter, $N^{\circ} 955$ June 23, 2001.) No wonder billions of birr (millions of dollars) continue to disappear from government coffers despite the Auditor-General's warnings (Addis Fortune June 8, 2015, June 14, 2016.)

The FEACC never cared to investigate the scandal-prone Norwegian nitrate fertilizer maker Yara that paid Mr. Zenawi $\$ 200,000.00$ and an artwork of undisclosed value (Ayele August 25, 2005). As expected, Yara subsequently “... won some major contracts in Ethiopia, just three months after it awarded a controversial prize to the late Ethiopia's Prime Minister." ${ }^{\prime 2}$ The FEACC never cared to investigate the tender bidding scandal of the Tendaho sugar projects. It never cared to investigate the ubiquitous no-bid contracts and tenders such as the no-bid contracts given to (1) the Chinese

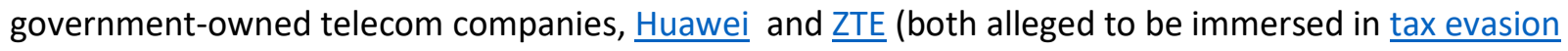
and procurement scandals); (2) Salini Costruttori in regards to Gilgel Gibe II \& III_International Rivers n.d.; Huffington Post May 25, 201) and Grand Ethiopian Remanence Dam-GERD); (3) companies owned by individuals who are closely associated with the ruling party (examples include: the Legedenbi gold mine that was given on concession to MIDROC as reported by The Reporter Saturday, 03 October 2009.) The FEACC never dared to look into the procurement scandal that involved the Ethiopian Commodity Exchange-ECX. In early 2008, the country's' National Bank was caught trying to extort 16 million dollars' worth of fake gold bars - the gold bars being replaced with gilded irons while sitting in its impenetrable secure vaults (World Bank 2012: 413).

By the ruling party's admission, maladministration and corruption are rife in Ethiopia. For example, in 2012, the two influential men and power brokers of the ruling party and founders of the TPLF, Mr. Sebhat Nega (patriarch of the Front) and the late Prime Minister Meles Zenawi admitted the country was indeed infested with a high level of corruption. In his February 2012 address to parliament,

\footnotetext{
${ }^{30}$ A good example is Mr. Ali Sulieman, the head of the FEACC and former Minister of Justice, who transferred and promoted to an ambassadorship position.

${ }^{31}$ Critiques of Mr. Zenawi's actions (such as Belai 2004), were quick to lament Mr. Zenawi's use of the FEACC to hound his political opponents while at the same time absolving his closest allies (even without any investigations.) They argue that he was acting as both the prosecutor and the judge (tactics that his successors use to this day.) Their allegations that the FEACC members are patronage hires - appointed not because of their capabilities and commitments to fighting corruption but because of their willingness to show the quick allegiance to Mr. Zenawi and their fear of being arrested, etc. were true. What is not true is the implications of their arguments that these same officials were clean of corruption.

32 Anonymous (2006: 136-43) documents this same Yara connection the "in your face" type of corruption committed by the late Mr. Zenawi and Yara.
} 
Hassan: Corruption, State Capture and the Effectiveness of Anti-Corruption Agency in PostCommunist Ethiopia

for example, the late Zenawi was observed expressing his frustration about the rampant corruption in the country (the main perpetrators of corruption being the highly rent-seeking government officials whom he called 'thieves within his government' and 'robbers within the people.') Commenting on the growing endless illicit financial outflows and endless grand scale theft of public money ${ }^{33}$ (Freitas 2011; Wall Street Journal Dec 5, 2011; Global Integrity 2011, 2015; Bloomberg Mar 3, 2017) and complaining about the grabbing and hoarding of prime lands and expensive properties in the major cities of the country by the top brass of the political cadres and the military (World Bank, 2012; Hassan 2016), Mr. Zenawi told his audience that he happened to know that many of them own several real estate properties, having them registered under their names, their spouses, their small children and even under their dogs' names. These are the same folks that Mr. Zenawi (in mid-2011) accused them of stashing \$2 billion in overseas banks and real estate assets. In a follow-up to a parliamentary address, which was delivered in March 2012 (Zenawi: March 17, 2012), he seemed to be subdued and even sounded defeated ${ }^{34}$ by the suffocating extent of corruption in the country. He admitted that he had come to learn that going after corrupt officials was insufficient, perhaps even an exercise in futility and an unwinnable war, for, according to him, corruption in Ethiopia happened to have elephant owners and those entrenched into it are fighting the government reform efforts tooth and nail. On February 22, 2012, Mr. Nega lamented about the pervasive nature of corruption in the country to the extent of castigating both the FEACC and the government for its unwillingness to fight corruption. Corruption is so rampant, he argued, it has even permeated the religious institutions. Justifying his measures for sacking the anti-corruption commissioner in 2002, the late Zenawi is also known to have accused the commissioners as visionless and short-sighted. ${ }^{35}$ In an interview he gave to the Guardian in January 2016, the Ethiopian government spokesperson, Mr. Getachew Reda, linked the 2015-2016 Oromo uprising to 'massive corruption'36 37 . Cheap talks about corruption are indeed common. For example, mimicking his late former boss, the current Prime Minister, Hailemariam Desalegn gave similar speeches to Parliament telling them that corruption was an existential problem (Hussein Sept. 19, 2016, AllAfrica.com Nov 16, 2015).

In early 2015, the results of a 3-month Parliament sanctioned study on governance and corruption was presented to the Parliament. The head of this same special investigative parliamentary group told the members of the House of Peoples' Representatives that the country was mired in rampant corruption and rent-seeking activities. ${ }^{38}$ The leader of the group, sitting down side-by-side with

\footnotetext{
33 David Steinman (August, 8, 2017) estimates, based on Thabo Mbeki's 2015 Illicit Financial Flows Report, TPLF's theft in the form of illicit financial flows amounts $\$ 2$ billion a year, leaving the country to be permanently insolvent.

${ }^{34}$ Some observers believe this is a one evidence indicating of a politico-economic system, built on graft, being unable to curtail unruly criminal gangs bent solely on their own enrichment.

35 However, Milkias (2001), Belai (2004) and many others believe the sacking was politically motivated and designed to strike "political blows on certain individuals and groups" many times insinuating presumption of guilt geared towards impacting prosecutors and judges who have yet to review the charges (The Reporter Aug. 5, 2017.). ${ }^{36}$ Many wonder why it has become customary for the ruling party to admit its administration being plagued by fraud and massive corruption but at the same time deceptively present as if hidden villains and faceless individuals commit fraud and corruption. Many observers attribute this narrative being used by the ruling party to placate donors and angry citizens while avoiding responsibility and with no progress being made in uprooting corruption.

${ }^{37}$ Despite the government's rhetoric that the protests were legitimate and corruption is to blame, the regime imposed a state of emergency from October 2016 to the end of July 2017, using it to imprison opposition leaders and put tens of thousands in concentration camps (Al, February 13, 2017; March 30, 2017; HRW, March 9, 2017) and expropriations of properties belonging to private citizens (Hassan: personal interview). 38 That study, as presented to the Ethiopian Parliamnet, had many flaws, however. For one, the study failed to include regional states such as Oromia, Gambela and Benishangul-Gumuz. Second, the study/report failed to include corruption related to land administration (land grabs), human trafficking, illicit financial flows and money
} 
Hassan: Corruption, State Capture and the Effectiveness of Anti-Corruption Agency in PostCommunist Ethiopia

Prime Minister Desalegn, zeroed in on the FEACC itself, thereby exposing it for its corrupt tendencies ${ }^{39}$. However, when deputy commissioner of the FEACC, Wedo Atto, begun talking about corruption, one of the MPs angrily told him (rough translation):

You repeatedly come here to tell us about increasing embezzlement and corruption, which we are tired of hearing, but we never see you bringing those government officials who have repeatedly been implicated in corruption cases to justice. We have already provided the anti-corruption laws needed which would allow you to prosecute the transgressors... but your commission rarely goes after the fraudsters. ${ }^{40}$

On the following week, many members of the Parliament used this opportunity and hopped up on the FEACC attack bandwagon, perhaps wanting to discredit and incapacitate it finally (and perhaps again before it uses its limited investigative power to expose their corrupt practices.)

Prime Minister Desalegn now tells us that a special anti-corruption investigative unit is established. Over 60 mid and low officials continue to be arrested and charged with corruption since then (Reuters Aug. 4, 2017; Addis Fortune August 11, 2017.) One may ask: Why would it take a special investigative unit to ascertain whether so many government officials are deeply involved in corruption. Why did the FEACC fail to detect and rectify the problem for so long? Why does the FEACC garner so much criticism from researchers and ridicule from both the public and the high-level officials?

Critics and investigators point out several reasons for the failure of the FEACC (see, for example, Tamyalew, 2010; Mezmur and, 2011; Megiso, 2007; Milkias, 2001/2003; Belai, 2004; Ayalew, 2005). They range from lack of sufficient resources and competent personnel whose credentials as independent investigators are known to genuine commitment and cooperation from political leaders and even to a lack independence ${ }^{41}$ and powers to meet the challenging tasks. While not dismissing the above factors, we argue in this paper that the failure is more fundamental than what critics suggest. Nevertheless, the criticisms labeled on the FEACC by members of Parliament indicate three basic facts having relevance to the concept of state capture: (a) an institutional weakness of the FEACC (as a government entity); (b) the FEACC just being a façade; and (c) a strong desire on the part of the Parliament to capture the FEACC and incapacitate it, once and for all. That may be why Prime Minister Desalegn told Parliament and the public that "[a new] investigation bureau was established under the auspices of the Ethiopian Federal Police to fight corruption and to hold accountable those involved in corruption ${ }^{42 "}$ (AllAfrica.com January

laundering. Thirdly, the study/report failed to provide the causes of the rampant corruption and posssible remedies. Fourthly, and most importantly, the report only implicates mid to lower-level government appointed individuals (regional, state and local, excluding high-level officials) as if the Ethiopian corruption conundrum represents administration type of corrupition (as opposed to being state capture). And, finally, we have yet to see (as of this writing) any serious measures taken by the ruling party to rectify the problem.

39 Indeed, local newspapers and individuals have reported dealing with the corruptive tendencies of the FEACC, thereby corroborating Mr. Sibhat Nega's and members of the parliament's claims. However, the coordinated attack against the FEACC by high-ranking officials and groups who themselves are corrupt, could well be a preemptive strike against the FEACC in order to stymie its efforts and prevent themselves from being investigated. The accusation, no doubt, would increasingly weaken the anti-corruption agency.

40 The Reporter has also reported the same in its February 12, 2016 edition.

${ }^{41}$ A good example, in regards to FEACC's lack of independence, is the statement made by Commissioner Ali Suleiman of the EFACC who told parliament on May 14, 2013 that FRACC's investigation began "two years ago with a direct order from former Prime Minister, the late Meles Zenawi." This admission attests to the claims we made earlier: that investigations of relatively high-ranking officials emanate from top leaders of the party, not from the FEACC.

42 The ruling party has yet to rescind past proclamations pertaining to the establishment and function of the FEACC. The establishment of a new anticorruption group directed by the Federal Police without rescinding the percolations all but guarantees overlapping jurisdictions between the two anti-corruption agencies, while at the same time 
Hassan: Corruption, State Capture and the Effectiveness of Anti-Corruption Agency in PostCommunist Ethiopia

9, 2017). Stripped of most of its power, the FEACC is now ordered to vacate the headquarter it occupies (The Reporter July 01, 2017 and July 15, 2017.) One of the requirements for an ACA's effectiveness is guaranteed permanence ( $\mathrm{TI} \underline{\text { n.d.) }}$.) Ethiopian authorities' actions to bypass the FEACC for going after corrupt individuals and dismantling the commission altogether shows the farcical nature of the FEACC. And as is customary, the regime has now begun announcing its politically motivated, largely overhyped and controversial arrests officials and businesspersons (as if corruption is an overnight affair), thereby accusing them of their involvement in corruption (Aigaforum.com, July 26, 2017; The Reporter, 29 July, 2017 and Aug, 5, 2017. ${ }^{43}$ ) Never mind the fact that, as recently as January 28, 2016, the pro-government local newspaper, The Reporter, reported (in its Amharic version) that the country's Auditor General and some members of parliament accused officials at the Ministry of Mines for being silent while the country is being robbed in broad daylight by corrupt officials, with several millionaires springing up overnight. More than a decade and a half in existence, even the FEACC acknowledges corruption "occurring in higher places than we had previously expected" (Catholic Online, 2013).

Nevertheless, these direct and repeated acknowledgments of corruption by high-ranking officials corroborate the claims that researchers and practitioners have repeatedly been making. Ethiopia not only is riddled with corruption but also the country is more corrupt today than in the past.

\section{Conclusion}

This paper attempted to show why the Ethiopian anti-corruption agency failed to curb the level of corruption in the country. The FEACC failed because of a host of reasons that many anti-corruption initiatives have fallen apart: lack of power to prosecute accorded to the FEACC and continuous political interference by top ruling party officials; lack of sufficient resources and well-trained personnel; lack of independence, impartiality, neutrality, integrity and competence on the part of appointed anticorruption officials. Add to this the alleged "mushrooming corruption in FEACC" that made the agency vulnerable to increasing attacks by government officials. Furthermore, the FEACC failed because of the lack of the supporting casts (World Bank, 2010): the non-existence of independent and effective judiciary, independent civil society and vibrant media (de Speville 2008.) FEACC's missteps exacerbated the problems: The FEACC squandered resources and its reputation by going only after the "small fish" while at the same time letting the "big fish" to swim (Mengistu et al., 2013; Arriola 2011: 251; Capital, June 1, 2015; The Reporter 13 Feb 2016.) The FEACC failed because of Mr. Zenawi's use of the agency as his tool to incapacitate his political opponents while at the same time shielding his collaborative cronies. As we illustrated in the body of the paper, the regime used donor funds to establish and run the FEACC. Critics point to this fact as being more evidence to the common practice of the TPLF both as ruling party and as a Front: defrauding and blackmailing donors.

As theorized by Persson and Teorell (2013), Heilbrunn (2004) and Johnston (1996), the main argument of this paper, however, is this: the war against corruption collapsed because of mischaracterization of the nature of corruption in Ethiopia and the ways in which the FEACC was based on - a standard anti-corruption agency for a non-standard problem. The donors are just as culpable for the failure of the anti-corruption agency. They pushed for and funded the establishment of a generic anti-corruption agency to solve a non-generic corruption system- state capture. They allowed their funds and the FEACC to be used for political purposes thereby compromising the integrity of donor aid and making the entire anti-corruption process to be a farce.

\footnotetext{
confirming the political nature of the Ethiopian "war on Corruption."

${ }^{43}$ This drama, i.e., the "anticorruption and corruption-prosecution con game," which involves the announcement of names of individuals suspected of corruption destined to maximize the fanfare, is taking place while at the same time high-level corrupt officials, such as Berhane Gebre-Christos, continue to engage in visible nepotistic activities.
} 
Hassan: Corruption, State Capture and the Effectiveness of Anti-Corruption Agency in PostCommunist Ethiopia

What we observe in Ethiopia is not just collusion between business elites and government officials. Corruption in Ethiopia is not just business elites working hand-in-glove with politicians to close off opportunities to competitors, which is also the case. What we see in Ethiopia is a state penetrated and ruled by criminals with high position of authority who unabatedly continue subverting it. What we observe in Ethiopia is a legally corrupt system (Geberamanuel July 4, 2013; Mekonnen July 24, 2013; Hassan 2008.) What we observe in the country is highly networked captors who are engaged in a full range of illicit and licit corrupt activities, a criminal group who have manufactured a criminal state (Bayart et al. 1999: 15, 25, 26, 101, 109; Hassan 2008). This is a corruption phenomenon which could be characterized a "state -within a state" (Miklaucic and Naím 2013), also one that largely is engineered by the state itself.

The failure to curb corruption by the FEACC has immense implications for the country and the people of Ethiopia. These include, among other things, eroding credibility to the FEACC (or any anticorruption efforts by any authority that the government establishes.) It leads to increasing public despair, cynicism, indifference in regards to the war on corruption and ultimately the government's ability to govern. The issue has already forced the ruling party repeatedly admit that corruption is systemic, to the extent that the ruling party has even accused the FEACC itself being immersed in corruption. It has led to uprisings and losses of lives and destruction of economic structures (Hassan Feb 18, 2016; Voanews.com Oct. 2, 2016).

Why would the world community have to be concerned about systemic corruption in Ethiopia? It is because, for the country itself, corruption has undermined the ruling party's governance abilities leading to public anger, unrest, and protests (see also Addis Standard Jan. 16, 2017), with the country being less peaceful (Global Peace Index 2017.) It is because persistent greed and opportunism of TPLF leaders and their cronies have created a political crisis. Evidence indicates that the country has been on the verge of being a failed state, which in turn has serious implications for the country and the world at large. It is because corruption and political instability have afflicted the country with weak flows of foreign direct investment and economic growth (Tenna 2017). It is because corruption has led to contested legitimacy (Sarbo 2009.) The current popular discontents and uprisings, with all their dire global security and sustainability implications, have been predicted by the NATO Parliamentary Delegation that visited Ethiopia in 2010. Among other things, the NATO group states:

The government rules in a kind of commando fashion rather than building up strong governance institutions. This leads to a personalization of politics, which raises important questions about the longterm sustainability of the current order.

It appears that ruling a country in "commando fashion" has reached its limits. The country's current political turmoils seem to indicate that the regime's doctrine of corruption and patronage has come to bite it hard. And no declaration of war on corruption and abuse of power, no deep renewals of the party, and not even renewed fanfares of arrests of a good number of corrupt officials could save the regime.

Future research may include exploring avenues in reforming the Ethiopian governance structure, including the ways of restructuring and privatizing of party-owned conglomerates; ways of discarding the corruption-infested "mammoth military-industrial complex", MeTECH, and constraining the reaches of MIDROC Ethiopia and restructuring the country's corporate governance system (Minga Negash 2013; Mulugeta July 19, 2013.) 
Hassan: Corruption, State Capture and the Effectiveness of Anti-Corruption Agency in PostCommunist Ethiopia

\section{References}

Abbink, John. 2009. "The Ethiopian Second Republic and the Fragile 'Social Contract,"' Africa Spectrum 2009, Vol. 44 , No. 2, pp. 3-28.

Abebe, Adem. April 2012. "Rule by Law in Ethiopia: Rendering Constitutional Limits on Government Power Nonsensical." CGHR Working Paper 1, Cambridge: University of Cambridge Centre for Governance and Human Rights. http://ehrp.org/wp-content/uploads/2014/05/Adem-Abebe-Rule-By-Law-in-Ethiopia.pdf

Abegaz, Berhanu. 2011. "Political Parties in Business." http://economics.wm.edu/wp/cwm wp113.pdf.

Abraha, Seeye, Former politburo member of the TPLF, former defense minister. October 2009. (Personal communications,)

. Investigation of testimonials of several of his write-ups and interviews from other outlets to assure consistency and truthfulness.

Action Professionals' Association for the People (APAP). April 2001. "An Overview of Corruption about the Ethiopian Legal System."

file:///C:/Users/Seid/AppData/Local/Temp/an\%20overview\%20of\%20corruption\%20relationa\%20to\%20 the\%20ethiopoan\%20legal\%20system.pdf.

Africa Watch Report/ Human Rights Watch. 1991. "Evil Days: 30 Years of War and Famine in Ethiopia." http://www.hrw.org/sites/default/files/reports/Ethiopia919.pdf.

Alemu, Ashebir. May 6, 2006. "Zenawi's Courts and Political Dissent: 'Ethiopian Judiciary without Justice."' http://www.sudantribune.com/spip.php?article15432.

Alesina, Alberto, and Beatrice Weder. May 1999. "Do Corrupt Governments Receive Foreign Aid?" NBER Working Paper No. 7108.

https://dash.harvard.edu/bitstream/handle/1/4553011/alesina corruptgovernments.pdf.

Allo, Awol. 30 November 2012. "The 'Politics' in Ethiopia's Political Trials." http://www.opendemocracy.net/awol-allo/politics-in-ethiopias-political-trials. and Beza Tesfaye. 2015. "Spectacles of illegality: mapping Ethiopia's show trials." http://eprints.Ise.ac.uk/64584/1/ Ise.ac.uk storage LIBRARY Secondary libfile shared repository Co ntent Allo\%2C\%20A Spectacles\%20of\%20illegality Allo Spectacles\%20of\%20illegality 2015.pdf.

Amundsen, Inge. 1999. "Political Corruption: An Introduction to the Issues." Working Paper 1999:9 (Chr. Michelsen Institute). http://www.cmi.no/publications/file/1040-political-corruption.pdf.

Anonymous. 2006. From Bullet to the Bank Account: report on the economic empire of Ethiopian People's Revolutionary Democratic Front (EPRDF). Addis Ababa, (6th update).

Araia, Ghelawdewos. May 13, 2013. "Behind the Façade of Corruption in Ethiopian and What the Government

Out to Do." http://www.tigraionline.com/articles/rent-seeking-corruption.html.

Araya, G/Medhin, a Former party member of the TPLF and administrator of finance, (personal communications, December 10, 2009) and investigations of several of his write-ups and interviews (in Amharic).

Arnold Anne-Katrin and Sumir Lal (2012). "Using Media to Fight Corruption.: https://ptfund.org/wpcontent/uploads/2013/03/15-PAPER-Using-Media-to-fight-Corruption.pdf.

Arriola, Leonardo R. 2008, 2011. Countries at the Crossroads 2011: Ethiopia. http://www.freedomhouse.org/sites/default/files/inline images/ETHIOPIAFINAL.pdf. . "Countries at the Crossroads 2011: Ethiopia. Freedom House. https://freedomhouse.org/sites/default/files/inline images/ETHIOPIAFINAL.pdf. , Terrence Lyons, and Simegnish Yekoye Mengesha 2016. "Ethiopia's 100\% Election." Journal of Democracy, January 2016, Volume 27, Number 1. http://www.ned.org/wpcontent/uploads/2016/01/JoD-Jan-2016-Ethiopia-Silencing-Dissent-Mengesha.pdf.

Assefa, Bogale. 2004. The Big Scandal: TPLF Business Empire. Addis Ababa: Commercial Printing Press (in Amharic).

Ayalew, Shimelis. 2005. "Corruption and Anti-Corruption in Ethiopia: A Study of the Ethiopian Customs Authority. Master's Thesis, Addis Ababa University. 
Hassan: Corruption, State Capture and the Effectiveness of Anti-Corruption Agency in PostCommunist Ethiopia

Ayele, Negussay. n.d. "EPLF/TPLF and Ethiopia-Eritrea Today: Sow the wind; reap the whirlwind." http://www.ethiopians.com/Views/Ethiopia Eritrea today.htm.

Aynekulu, Awualom, 1996. "The Ethiopian Economy: A Look at the TPLF Sponsored Millionaires/Monopolies Part I." Ethiopian Register, July 1996, [20-31].

(1996). "The Ethiopian Economy: A Look at the TPLF Sponsored Millionaires/Monopolies -Part II." Ethiopian Register, August 1996, [14-22]

Ayalew, Shimelis, 2005. "Corruption and Anti-Corruption in Ethiopia: A Study of the Ethiopian Customs Authority. Master's Thesis, Addis Ababa University.

Banti, Wardoffa. 2008. "Systemic and Systematic Corruption in Ethiopia under Meles Zenawi," http://www.abugidainfo.com/?p=4351.

Bardhan, Pranab K. 2006. The Economist's Approach to the Problem of Corruption. World Development, 34 (2), pp.341-8. http://eml.berkeley.edu/ webfac/bardhan/papers/number5.pdf.

Baskind, Roy. n.d. "Corruption siphons AIDS money: Human greed compounds the misery of the HIV epidemic in sub-Saharan Africa." http://www.pamoja.at/oldsite/Press Archives/Corruption siphons AIDS money.pdf.

Bauhr, Monika. \& Nasiritousi, Naghmeh. 2011. "Why Pay Bribes? Collective Action and Anti-Corruption Efforts. QOG Institute." http://www.sahlgrenska.gu.se/digitalAssets/1357/1357856 201118 bauhr nasiritousi.pdf.

Bavister-Gould, Alex. 2011. "Predatory Leaderships, Predatory Rule and Predatory States." http://publications.dlprog.org/Predatory\%20leaderships,\%20predatory\%20rule\%20and\%20predatory\% 20states.pdf.

Jean-François Bayart, Stephen Ellis, and Béatrice Hibou. 1999. The Criminalization of the State in Africa, London: Villiers Publications.

Bazezew, Arega. 2012. "Productive Safety Nets Program and Household Level Graduation in Drought-Prone Areas of the Amhara Region of Ethiopia: A Case Study in Lay Gaint District." Ethiopian Journal of Environmental Studies and Management, Vol. 5 no.4 (Suppl.2) 2012: 604-612.

Belai, Abraha, Former member of the TPLF, (personal communication, December 11, 2009).

Belai, Elizabeth. 2004. "Disabling a Political Rival Under the Cover of Fighting Corruption in Ethiopia: The Case of Prime Minister Meles Zenawi Versus Ex-Defense Minister Seeye Abraha."

http://www.aigaforum.com/TheCaseofSiye.pdf,

Berhanu, Kassahun. n.d. "Ethiopia: Beleaguered Opposition under a Dominant Party System." http://www.cmi.no/file/?1315.

Berhe, Aregawi. 2009. A Political History of the Tigray People's Liberation Front (1975-1991): Revolt, Ideology, and Mobilisation in Ethiopia. Tsehai Publishers (July 1, 2009).

. (Former politburo member of the TPLF). Testimonials of several of his write-ups and interviews from other outlets.

Black, Bernard, Reinier Kraakman and Anna Tarassova. n.d. "Russian Privatization and Corporate Governance: What Went Wrong?" http://siteresources.worldbank.org/INTDECINEQ/Resources/black.pdf.

Bogale Assefa. 2004. The Big Scandal: TPLF Business Empire. Addis Ababa: Commercial Printing Press (in Amharic).

Bouchet, Michel \& Bertrand Groslambert. 2006. "An Empirical Study of The Relationships between Corruption, Capital Leakages, and Country Risk: Part I." http://www.esan.edu.pe/paginas/publicaciones/cuadernos/20/Bouchet.pdf.

Boyce, James K. \& Léonce Ndikumana.October. 2012. "Capital Flight from Sub-Saharan African Countries: Updated Estimates, 1970 - 2010."

http://www.peri.umass.edu/fileadmin/pdf/ADP/SSAfrica capitalflight Oct23 2012.pdf. 
Hassan: Corruption, State Capture and the Effectiveness of Anti-Corruption Agency in PostCommunist Ethiopia

Brigaldino, Glenn. 2011. "Elections in the imperial periphery: Ethiopia hijacked." Review of African Political Economy, 38 (128): 327-334.

Briscoe, Ivan, October. 2008. "The Proliferation of the 'Parallel State.'” http://fride.org/descarga/WP71 Paralell state ENG oct08.pdf.

Broadman, H. G. \& Recanatini F. 2001. Seeds of Corruption: Do Market Institutions Matter? World Bank: Policy Research Working Paper 2368. http://unpan1.un.org/intradoc/groups/public/documents/apcity/unpan019158.pdf.

Carr, Indira. 2009. "Corruption, the Southern African Development Community Anti-Corruption Protocol and the Principal-Agent-Client Model." International Journal of Law in Context, Vol. 5, No. 2, pp. 147-177, 2009.

Center for International Human Rights, Northwestern University School of Law. 2009. "Sounding the Horn: Ethiopia's Civil Society Law Threatens Human Rights Defenders." http://www.law.northwestern.edu/legalclinic/humanrights/documents/EthiopiaCSOPaperNov2009.pdf.

Chang, Eric C. C. \& Nicholas N. Kerr. 2009. "Do Voters Have Different Attitudes toward Corruption? The Sources and Implications of Popular Perceptions and Tolerance of Political Corruption." https://www.files.ethz.ch/isn/110435/AfropaperNo116.pdf.

Chanie, Paulos. 2007. "Clientelism and Ethiopia's Post-1991Decentralisation." J. of Modern African Studies, 45, 3 (2007), pp. 355-384.

Charap, Joshua, \& Christian Harm. 1999. "Institutionalized Corruption and the Kleptocratic State," IMF Working Paper \#99/91. http://www.imf.org/external/pubs/ft/wp/1999/wp9991.pdf.

Coronel, Sheila, ed. 1997. "Pork and Other Perks: Corruption and Governance in the Philippines." Manila: Institute for Popular Democracy, Philippine Center for Investigative Journalism and Evelio B. Javier Foundation. See Chapter 5, in particular, which as https://www.hks.harvard.edu/fs/pnorris/Acrobat/WorldBankReport/Chapter\%205\%20Coronel.pdf.

Creswell, John. 2008. Educational research: Planning, conducting, and evaluating quantitative and qualitative research. (Third Ed.). Upper Saddle River, NJ: Pearson Education, Inc.

Darden, Keith. 2002. "Graft and Governance: Corruption as an Informal Mechanism of State Control." https://www.files.ethz.ch/isn/30472/2002-02.pdf.

Debalke, Teshome. November 30, 2012. "Ethiopia: The Morality of Development and its Operatives." http://www.oaklandinstitute.org/ethiopia-morality-development-and-its-operatives.

Demissie, Ejigou (Amharic). 1996. "TPLF Administration and the State of Ethiopia's Economy" in two parts, Ethiopian Register, Aug. /Sep. 1996).

Dimitrov, Martin K. 2009. "From Spies to Oligarchs: The Party, the State, the Secret Police and Property Transformations in Post communist Europe." http://www.democracy.uci.edu/files/democracy/docs/conferences/dimitrov.pdf.

Disch, Arne, Endre Vigeland, Geir Sundet, \& Sam Gibson. 2009. “Anti-Corruption Approaches: A Literature Review." http://www.sida.se/contentassets/3f5c8afd51a6414d9f6c8f8425fb935b/anti-corruptionapproaches-a-literature-review 3153.pdf.

Easterly, William \& Laura Freschi. 2010. "Why Are We Supporting Repression in Ethiopia?" http://www.nybooks.com/blogs/nyrblog/2010/nov/15/why-are-we-supporting-repression-ethiopia/.

Dutta, Diya. December 2009. "Elite Capture and Corruption: Concepts and Definitions https://www.academia.edu/237917/Elite Capture and Corruption Concepts and Definitions.

Economic Commission for Africa (ECA). 2015. "Report of the High-Level Panel on Illicit Financial Flows from Africa." http://www.uneca.org/sites/default/files/PublicationFiles/iff main report 26feb en.pdf. . 2010. "Assessing the Efficiency and Impact of National Anti-Corruption Institutions in Africa: Governance and Public Administration Division." http://anticorruption.org/pmb321/pmb/opac css/doc num.php?explnum id=18. 
Hassan: Corruption, State Capture and the Effectiveness of Anti-Corruption Agency in PostCommunist Ethiopia

Ellerman, David. 2001. "Lessons From East Europe's Voucher Privatization." http://cog.kent.edu/lib/Ellerman5.htm.

Ethiopian Register. 1996. "TPLF/EPRDF's Strategies to Establish its Hegemony and Perpetuating its Rule," an abridged translation by ER of an EPRDF document issued in 1993 in Amharic, Ethiopian Register, pp. 2029.

No. 4, July 1997. "Meles Declares Political Loyalty Factor In Appointment To Senior Government Officials." pp. 20-23.

No 5, April 1998. "Graduates without Experiences Appointed Judges." P. 98.

Fiseha, Assefa, 2012. "Separation of powers and its implications for the judiciary in Ethiopia." Journal of Eastern African Studies, Volume 5, 2011 - Issue 4: Ethiopia's revolutionary democracy, 1991-2011.

Fjeldstad, Odd-Helge, and Jan Isaksen. 2008. "Anti-Corruption Reforms: Challenges, Effects and Limits of World Bank Support." IEG Working Paper 2008/7. http://siteresources.worldbank.org/EXTPUBSECREF/Resources/Fjeldstad anticorruption.pdf.

Freitas, Sarah, and Global Integrity. 2011. "Illegal Ethiopian Capital Flight Skyrocketed In 2009 to US\$3.26 Billion." http://www.financialtaskforce.org/2011/12/05/illegal-ethiopian-capital-flight-skyrocketed-in2009-to-us3-26-billion/ and http://iff.gfintegrity.org/iff2012/2012report.html.

Gebeye, Berihun. 2015. "The Legal Regime of Corruption in Ethiopia: An Assessment from International Law Perspective." Joornaalii Seeraa Oromiaa [Jil.4, Lakk. 1] Oromia Law Journal [Vol.4, No.1]. https://www.ajol.info/index.php/oli/article/viewFile/120612/110062.

Gelaw, Abebe. 2011. "TPLF found in global terrorism blacklist." http://ethiomedia.com/andnen/2957.html.

Gailmard, Sean. 2012. "Accountability and Principal-Agent Models." https://www.law.berkeley.edu/files/csls/Gailmard - Accountability and PrincipalAgent Models(2).pdf.

Gebeye, Berihun Adugna. 2011. "Rethinking International Anti-Corruption Conventions: Advancing CorruptionFree Service as a Human Right.” https://chilot.files.wordpress.com/2013/01/rethinking-internationalanti-corruption-conventions.pdf.

G/Tensae, General Tsadikan (former Chief of Staff of Ethiopian Defense Forces). Jul 24 2016. “PY7L年\}

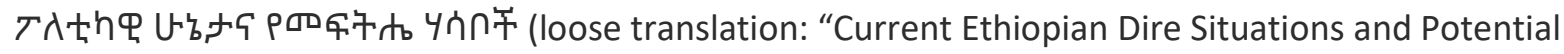
Solutions." http://hornaffairs.com/am/2016/07/24/ethiopia-current-political-challengesrecommendations/.

Global Financial Integrity. 2015. "Illicit Financial Flows and Development Indices: 2008-2012." http://www.gfintegrity.org/wp-content/uploads/2015/05/Illicit-Financial-Flows-and-DevelopmentIndices-2008-2012.pdf.

Glória, Texeira and Ary Ferreira da Cunha. 2015. "Public Governance and Political Corruption: A Framework for Anticorruption Policy." http://www.gestaodefraude.eu/wordpress/wpcontent/uploads/2015/02/wp035.pdf.

Goldman, Marshall. 2004. "Putin and the Oligarchs." Foreign Affairs, November/December 2004 Issue. http://www.foreignaffairs.com/articles/60263/marshall-i-goldman/putin-and-the-oligarchs?page=show. .2003. The Piratization of Russia: Russian Reform Goes Awry. Routledge, London, and New York. http://www.e-reading.club/bookreader.php/135022/The Piratization of Russia.pdf

Groenendijk, Nico. 1997. “A principal-agent model of corruption.” Crime, Law \& Social Change 27: 207-229. Also http://doc.utwente.nl/77654/1/principal-agent.pdf.

Gudina, Merera. n.d. "Ethiopia: Transition without Democratization.” http://www.addisvoice.com/wpcontent/uploads/2010/03/ethiopia-transition-without-democracy.pdf. 
Hassan: Corruption, State Capture and the Effectiveness of Anti-Corruption Agency in PostCommunist Ethiopia

Guriev, Sergei and Andrei Rachinsky. n.d. "The Evolution of Personal Wealth in the Former Soviet Union and Central and Eastern Europe."

http://siteresources.worldbank.org/INTDECINEQ/Resources/Evolution of personal wealth.pdf. . 2005. "The Role of Oligarchs in Russian Capitalism." Journal of Economic Perspectives-Volume 19, Number 1-winter 2005-Pages 131-150 http://pages.nes.ru/sguriev/papers/GurievRachinsky.pdf

Hailu, Hishe. 2005. "An Assessment of the Process of Privatization in Ethiopia," Master's Thesis: http://etd.aau.edu.et/dspace/bitstream/123456789/795/1/Hishe\%20hailu.pdf.

Hanna, Rema, and Sarah Bishop, Sara Nadel, Gabe Scheffler and Katherine Curlacher. 2011. "The Effectiveness of Anti-corruption Policy: What has Worked, What hasn't, and What We Don't Know." Center for International Development at Harvard University. http://r4d.dfid.gov.uk/PDF/Outputs/SystematicReviews/Anti corruption 2011Hanna.pdf.

Hassan, Seid. Feb 18, 2016. "Ethiopia: The People Want Their Country Back." https://www.pambazuka.org/governance/ethiopia-people-want-their-country-back.

. 2013(a). "Aid, Predation, and State Capture: The Role of Development Aid in Fuelling Corruption and Undermining Governance: The Case of Ethiopia. Ethiopian e-Journal for Research and Innovation Foresight, Vol. 5, No. $1 * 51-53)$.

http://nesglobal.org/eejrif4/index.php?journal=admin\&page=article\&op=view\&path[]=102\&path[]=279.

.2013(b): "The State Capture Onset in Ethiopia: Humanitarian Aid and Corruption." Capture: The Role of Development Aid in Fuelling Corruption and Undermining Governance: The Case of Ethiopia. Ethiopian e-Journal for Research and Innovation Foresight, Vol. 5, No. 1 (51-53).

http://nesglobal.org/eejrif4/index.php?journal=admin\&page=article\&op=view\&path[]=101\&path[]=284.

. February 1, 2016. "Explaining the Soaring Ethiopian Real Estate and Property Prices."

http://www.pambazuka.org/governance/explaining-ethiopia\%E2\%80\%99s-soaring-real-estate-andproperty-prices

. February 13, 2016. "Ethiopia: Corruption and the Burning Down of Properties by Protesters. Should we condemn or condone it? Who's to Blame?" http://www.pambazuka.org/governance/ethiopia-peoplewant-their-country-back.

.2008. "The link between Ethno-centric minority rule and Corruption." https://abbaymedia.com/thelink-between-ethno-centric-minority-rule-and-corruption/.

Heilbrunn, John R. 2004. "Anti-Corruption Commissions Panacea or Real Medicine to Fight Corruption?" World Bank Institute. http://siteresources.worldbank.org/WBI/Resources/wbi37234Heilbrunn.pdf.

Hellman, Joel \& Daniel Kaufmann. 2000. "Confronting the Challenge of State Capture in Transition Economies." http://www.imf.org/external/pubs/ft/fandd/2001/09/hellman.htm

, Geraint Jones, \& Mark Schankerman. April 2000. “Measuring Governance, Corruption, and State Capture." http://siteresources.worldbank.org/INTWBIGOVANTCOR/Resources/measure.pdf. , and Schankerman, M. 2000. "Intervention, Corruption and Capture: The Nexus between Enterprises and the State." http://dss.ucsd.edu/ mnaoi/page4/POLI227/files/page1 27.pdf;

, Geraint Jones, Daniel Kaufmann Mark Schankerman. 2000. "Corruption, and State Capture: How Firms and Bureaucrats Shape the Business Environment in Transition Economies." World Bank and European Bank for Reconstruction and Development. Policy Research Working Paper 2312. http://unpan1.un.org/intradoc/groups/public/documents/un-dpadm/unpan044602.pdf. , 1998. "Winners Take All: The Politics of Partial Reform in Post-communist Transitions." https://www.ucis.pitt.edu/nceeer/1997-811-01-Hellman.pdf.

\& Daniel Kaufmann. 2003. "The Inequality of Influence" (http://www.worldbank.org/wbi/governance/pdf/inequality influence.pdf. 
Hassan: Corruption, State Capture and the Effectiveness of Anti-Corruption Agency in PostCommunist Ethiopia

, Geraint Jones, and Daniel Kaufmann. 2000. "Seize the State, Seize the Day. State Capture, Corruption, and Influence in Transition." World Bank, Policy Research Working Paper, No. 2444. Washington, D. C.: World Bank, 2000.

Human Rights Watch. October 2010. "Development without Freedom: How Aid Underwrites Repression in Ethiopia." http://www.hrw.org/sites/default/files/reports/ethiopia1010webwcover.pdf.

. 2010: "One Hundred Ways to Put Pressure: Violations of Freedom of Expression and Association in Ethiopia." http://www.hrw.org/sites/default/files/reports/ethiopia0310webwcover.pdf.

.2012. "Waiting Their for Death' - Displacement and 'Villagization' in Ethiopia's Gambella Region."

http://www.hrw.org/sites/default/files/reports/ethiopia0112webwcover_0.pdf. . October 2008. "Analysis of Ethiopia's Draft Civil Society Law."

https://www.hrw.org/news/2008/10/13/analysis-ethiopias-draft-civil-society-law.

International Crisis Group. 2009. “Ethiopia: Ethnic Federalism and Its Discontents: Africa Report N¹53 - 4

September 2009: http://www.crisisgroup.org/ /media/Files/africa/horn-of-africa/ethiopiaeritrea/Ethiopia\%20Ethnic\%20Federalism\%20and\%20Its\%20Discontents.ashx.

Iwasaki Kayizzi-Mugerwa. 2003. Privatization in sub-Saharan Africa: On factors affecting implementation. In S. Kayizzi-Mugerwa (Ed.). Reforming Africa's institutions: ownership, incentives, and capabilities (227-253). Tokyo: United Nations University Press.

Jacobs, Leslie Gielow \& Benjamin B. Wagner. 2007. "Limits of Independent Anti-corruption Commission Model of Corruption Reform: Lessons from Indonesia." 20 Pac. McGeorge Global Bus. \& Dev. L.J. 327.

http://digitalcommons.mcgeorge.edu/cgi/viewcontent.cgi?article=1013\&context=facultyarticles

Johnston, Michael. 2012. "Why Do So Many Anti-Corruption Efforts Fail?" NYU Annual Survey of American Law [Vol. 67:467-97). http://www.law.nyu.edu/sites/default/files/upload documents/NYU-Annual-Survey67-3-Johnston.pdf.

2005. Syndromes of Corruption: Wealth, Power, and Democracy. Cambridge University Press, New York, NY, USA, 2005.

. "Political and Social Foundations for Reform: Anti-Corruption Strategies for the Philippines." Asia Foundation: Center for Strategic and International Studies.

http://www.rvrcvstarr.aim.edu/MJ\%20Website\%20Pictures\%20(CVStarr)/Johnston\%20Book\%20(Nov.\% 2011,\%202010)/johnston book.pdf.

Joireman, Sandra F. and Thomas S. Szayna. 2000. “Chapter Five: The Ethiopian Prospective Case” pp. 193-233, in Identifying Potential Ethnic Conflict: Application of a Process Model. Rand Corporation. Santa Monica, California, Rand, 2000.

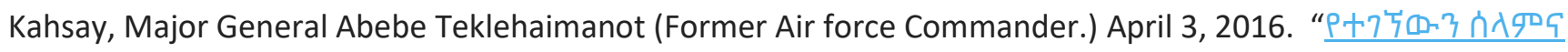

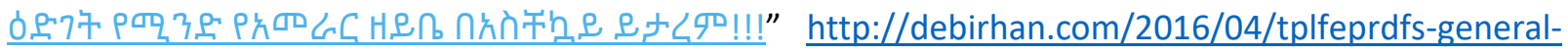
abebe-teklehaimanot-kahsay-critical-feature-on-ethiopias-present/. https://www.rand.org/content/dam/rand/pubs/monograph reports/MR1188/MR1188.ch5.pdf.

Karklins, Rasma. 2002. "Capitalism, Corruption, and something else: Typology of Post-Communist Corruption." Problems of Post-Communism, 49, 22-32. http://pdc.ceu.hu/archive/00001528/01/03Karklins[1].pdf.

Kaufmann, Daniel, and Paul Siegelbaum. 1996. "Privatization and Corruption in the Transition Economies." Journal of International Affairs, Winter, 1996, No. 2, (421-58). http://projects.iq.harvard.edu/gov2126/files/kaufmannsiegelbaum 1997.pdf.

Kebede, Gudeta. 2013. "Political Corruption: Political and Economic State Capture in Ethiopia." European Scientific Journal, European Scientific Journal, December 2013, vol.9, No.35 ISSN: 1857 - 7881 (Print) e ISSN 1857-7431.

Keeley, James, Wondwosen Michago Seide, Abdurehman Eid and Admasu Lokaley Kidewa. 2014. "Large-scale land deals in Ethiopia: Scale, trends, features, and outcomes to date. http://pubs.iied.org/pdfs/12575IIED.pdf. 
Hassan: Corruption, State Capture and the Effectiveness of Anti-Corruption Agency in PostCommunist Ethiopia

Keller Edmond J. 2002. "Ethnic federalism, fiscal reform, development, and democracy in Ethiopia." African Journal of Political Science 21, Vol. 7 No.1, 22- 50.

http://www.sscnet.ucla.edu/polisci/faculty/keller/papers/SelectedPub/EthnicFed.PDF.

Khemani, Melissa. 2009. "Anti-Corruption Commissions in the African State: Burying the Problem or Addressing the Issue?" Rochester: Social Science Research Network.

http://papers.ssrn.com/sol3/papers.cfm?abstract id=1334286\&download=yes

Kidan, Tesfaye. "Unequal Playing Field Becomes Breeding Ground for Corruption." Addis Fortune, Volume 11, Number 538, Published On August 22, 2010.

http://www.addisfortune.com/Vol\%2010\%20No\%20538\%20Archive/ecconomic commentary.htm .

Kilimanjaro International Corporation Limited. 2012. "Ethiopia Second Corruption Perception Survey," Volumes

1 and 2, January 2012.

Klitgaard, Robert. 1988. Controlling Corruption (Berkeley and Los Angeles: University of California Press)

Kilimanjaro International Corporation Limited. 2012. "Ethiopia Second Corruption Perception Survey," Volumes 1 and 2, January 2012.

Lefort, René . 9 September 2016. "The 'Ethiopian Spring': 'Killing is not an answer to our grievances.'” https://www.opendemocracy.net/ren-lefort/ethiopian-spring-killing-is-not-answer-to-our-grievances.

Legesse, Ermias. 2014. Yemeles Tirufatoch Balebet Alba Ketema. Washington, DC: Netsanet Publishing, 2014.

Lensink, Robert, and White, Howard. 2000. "Aid Allocation, Poverty Reduction, and the Assessing Aid Report," Journal of International Development, Vol. 12, No. 3, pp. 399-412.

Marquette, Heather \& Caryn Peiffer. January 2015. "Corruption and Collective Action."

http://publications.dlprog.org/CorruptionandCollectiveAction.pdf.

Luckham, Rubin. 2002. "Radical Soldiers, New Model Armies and the Nation-State in Ethiopia and Eritrea), in Koonings, K. and Kruijt, D. (editors). Zed Press.

Marat, Erica. 2006. "The State-Crime Nexus in Central Asia: State Weakness, Organized Crime, and Corruption in Kyrgyzstan and Tajikistan."

http://www.silkroadstudies.org/resources/pdf/SilkRoadPapers/2006 10 SRP Marat State-Crime-

Central-Asia.pdf.

McCarthy, Daniel J. \& Sheila Puffer. 1995. "Diamonds and rust" on Russia's road to privatization: The profits and pitfalls for western managers." The Columbia Journal of World Business 30(3):56-69 • September 1995.

McCracken, Mathew. 2004. "Abusing Self-Determination and Democracy: How the TPLF is Looting Ethiopia." Journal of International Law 36(1) 183-222.

http://scholarlycommons.law.case.edu/cgi/viewcontent.cgi?article=1390\&context=jil.

Megiso, Tesfaye. S. 2007. "Anti-Corruption Efforts in Ethiopia."

http://www.nacf.org.za/global forum5/CVs/111.2\%20e\%20Shamebo.pdf.

Mbaku, John Mukum. 1996. "Bureaucratic Corruption in Africa: The Futility of Cleanups." Cato Journal, vol. 16, No. 1 (Spring/Summer 1996, pp. 90-118. http://object.cato.org/sites/cato.org/files/serials/files/catojournal/1996/5/cj16n1-6.pdf.

Mekonnen, Wondimu. 2013. "Ethiopia: Legally Corrupt." http://ecadforum.com/2013/07/24/ethiopia-legallycorrupt/.

Melnykovska, Inna \& Rainer Schweickert. 2008. "Who You Gonna Call? - Oligarchic Clans as a Bottom-up Force of Neighborhood Europeanization in Ukraine," http://www.oei.fuberlin.de/politik/publikationen/AP 67.pdf.

Melnykovska, Inna \& Rainer Schweickert. 2008. "Who You Gonna Call? - Oligarchic Clans as a Bottom-up Force of Neighborhood Europeanization in Ukraine," http://www.oei.fuberlin.de/politik/publikationen/AP 67.pdf.

Mengistu, Berhanu, Seid Hassan \& Tilahun Teklu. 2013. "Public Perceptions of Corruption in Ethiopia: Assessment and Descriptive Analysis.' International Journal of Business and Public Administration (IJBPA), Volume 10, No. 2, Fall, 2013: pp. 90-120 
Hassan: Corruption, State Capture and the Effectiveness of Anti-Corruption Agency in PostCommunist Ethiopia

\& Elizabeth Vogel. 2009. "Public Perceptions of Privatization in Ethiopia: A Case for Public Good or Private Gain?" International Journal of Public Administration, 32(8): 681-703.

Mersha, Genet. 31 January 2010. "Increased Role of Party-owned Enterprises in the Economy Raises Several Serious Concerns." http://www.abugidainfo.com/wp-content/uploads/2010/01/increasing-role-ofparty01.pdf. . 25th March 2008. "The Seeds of Resentment and Future Instability in Ethiopia," http://abbaymedia.com/News/?p=879.

Mewa, Berhane- former President of the Ethiopia and Addis Ababa Chambers of Commerce December 15, 2009. Personal interview) - Mr. Mewa was a one-time President of the Ethiopia and Addis Ababa Chambers of Commerce-

Mezmur, Tewodros, and Raymond Koen. 2011. The Ethiopian Federal Ethics and Anti-Corruption Commission: A Critical Assessment. Law, Democracy \& Development, 15(1): 215-43.

Milkias Paulos. 2001. "Ethiopia, TPLF, and Roots of the 2001 Political Tremor." International Conference on African Development.

http://homepages.wmich.edu/ asefa/Conference\%20and\%20Seminar/Papers/2001\%20papers/Paperlll 10.pdf.

2011. Africa in Focus: Ethiopia. ABC-CLIO, LLC. Santa Barbara, CA, 93116.

Mishler, William and Richard Rose. 2008. "Seeing Is Not Always Believing: Measuring Corruption Perceptions and Experiences." http://www.u.arizona.edu/ mishler/corrupt08-18-08.pdf.

Muhumuza, William. 2016. "The politics of Anti-Corruption Reforms and Reversals in Uganda's Changing Political Terrain," Economic and Political Studies, 2016 VOL. 4, NO. 1, 62-84. http://www.tandfonline.com/doi/full/10.1080/20954816.2016.1152095.

Mulataa, Zakaariyaas. 2010. "Political nongovernmental organizations (NGOs) and governmental companies in Ethiopia." http://www.oromoliberationfront.org/news/2010/Fake NGO of the TPLF (gullaala xummuraa)[1].pdf

Mungiu-Pippidi, Alina. 2013. "Contextual Choices in Fighting Corruption>: Journal of Democracy Volume 24, Number 1 January 2013.

Negash. Assefa. 1996. The Pillage of Ethiopia by Eritreans and their Tigrean Surrogates. Adey Publishers, Los Angeles.

Negash, Minga. 2013. "Corporate governance and ownership structure: The case of Ethiopia." Presented at the Conference on Good Governance, Peace, Security and Sustainable Development in Ethiopia and the Horn of Africa. Crystal City, VA (April 9-11, 2010).

Nellis, John. 2005. "Privatization in Africa: What has happened? What is to be Done? http://ageconsearch.umn.edu/bitstream/12200/1/wp050127.pdf.

Northwestern University School of Law, Center for International Human Rights. November 2009. "Sounding The Horn: Ethiopia's Civil Society Law Threatens Human Rights Defenders." https://www.law.northwestern.edu/legalclinic/humanrights/documents/EthiopiaCSOPaperNov2009.pdf.

Nowak, Robert. 1996/2001. "Corruption and Transition Economies." UN Economic Commission for Europe. http://www.unece.org/fileadmin/DAM/trans/osce/osceunece/misc corruption.pdf

Oakland Institute. November 30, 2012. "Ethiopia: The Morality of Development and its Operatives." http://www.oaklandinstitute.org/ethiopia-morality-development-and-its-operatives. . 2015. "We Say the Land is not Yours: Breaking the Silence against Forced Displacement in Ethiopia." Oakland, CA: Oakland Institute, 2015. http://www.oaklandinstitute.org/sites/oaklandinstitute.org/files/Breaking\%20the\%20Silence.pdf. 
Hassan: Corruption, State Capture and the Effectiveness of Anti-Corruption Agency in PostCommunist Ethiopia

. 2011. "Understanding Land investment deals in Africa- Country report: Ethiopia."

http://www.solidaritymovement.org/downloads/110608UnderstandingLandDealsInAfrica.pdf.

OECD. 2008. "Specialized Anti-Corruption Institutions: Review Of Models."

https://www.oecd.org/corruption/acn/39971975.pdf.

Ofcansky, Thomas P., and David H. Shinn. 2004. Historical Dictionary of Ethiopia. Scarecrow Press, Mar 29, 2004.

Omelyanchuk, Oleksiy. 2001. "Explaining State Capture_and State Capture Modes: The Cases of Russia and

Ukraine."

https://www.researchgate.net/publication/253679086 Explaining State Capture and State Capture Modes The Cases of Russia and Ukraine.

Persson, Anna, Bo Rothstein and Jan Teorell. July 2013. "Why Anticorruption Reforms Fail-Systemic Corruption as a Collective Action Problem." Governance: An International Journal of Policy, Administration, and Institutions, Vol. 26, No. 3, July 2013 (pp. 449-471).

http://weblaw.haifa.ac.il/en/JudgesAcademy/workshop3/Documents/A/D/Why\%20Anti-

Corruption\%20Fail.pdf; http://onlinelibrary.wiley.com/doi/10.1111/j.1468-0491.2012.01604.x/pdf.

Pieth, Mark. September 2012. "Collective Action and Corruption, International Centre for Collective Action, Working paper series No.13.

https://www.baselgovernance.org/sites/collective.localhost/files/publications/biog working paper 13. pdf

Plaut, Martin. 3 March 2010. "Ethiopia Famine Aid Spent On Weapons."

http://news.bbc.co.uk/2/hi/8535189.stm

Peebles, Graham. July 18, 2012.

https://www.counterpunch.org/2012/07/18/donor-dollars-aiding-political-repression-inethiopia/

Proclamation No. 433/2005, Addis Ababa: Federal Democratic Republic of Ethiopia. https://www.acauthorities.org/sites/aca/files/countrydoc/Proclamation\%20No\%20433-2005.pdf; or here: http://faolex.fao.org/docs/pdf/eth135248.pdf.

Regassa, Getachew. 2003. Privatization in Ethiopia: Process and Performance of Privatized Manufacturing Firms, Master's Thesis, Addis Ababa University, June 2003.

Rose-Ackerman, Susan. 2004. "The Challenge of Poor Governance and Corruption." http://www.copenhagenconsensus.com/sites/default/files/cp-corruptionfinished.pdf.

Ross, Tracy J. 2010. "A Test of Democracy: Ethiopia's Mass Media and Freedom of Information Proclamation." Penn State Law Review, Vol. 114:3, 1047-1066.

http://www.pennstatelawreview.org/articles/114/114\%20Penn\%20St.\%20L.\%20Rev.\%201047.pdf.

Rothstein, Bo. 2011. "Corruption and Risks Anti-Corruption: The Indirect 'Big Bang' Approach." Review of International Political Economy 18:2 May 2011: 228-250.

Sarup, Kamala. 19-Jul-05. "Corruption Increases Terrorism."

http://www.worldsecuritynetwork.com/Terrorism/Sarup-Kamala/Corruption-Increases-Terrorism.

Svensson, Jacob \& Reinikka, Ritva. (2004). "Local Capture: Evidence from a Central Government Transfer Program in Uganda." Quarterly Journal of Economics, 119(2): 679-705.

Shah, Anwar. 2007. In Performance Accountability and Combating Corruption,_edited by, Anwar Shah. The International Bank for Reconstruction and Development / The World Bank, Washington, DC. U.S.A. http://siteresources.worldbank.org/PSGLP/Resources/PerformanceAccountabilityandCombatingCorrupt ion.pdf.

Shimelis Ayalew. 2005. Corruption and Anticorruption in Ethiopia: A Case Study of the Ethiopian Customs Authority, MA Thesis, Addis Ababa University, Addis Ababa.

Slinko. Irina, Evgeny Yakovlev, \& Ekaterina Zhuravskaya. 2003. "Institutional Subversion: Evidence from Russian Regions." http://deepblue.lib.umich.edu/bitstream/2027.42/39990/2/wp604.pdf. 
Hassan: Corruption, State Capture and the Effectiveness of Anti-Corruption Agency in PostCommunist Ethiopia

Smith, Lahra, 2007. "Political Violence and Democratic Uncertainty in Ethiopia." United States Institue of PeaceSpecial Report. https://www.usip.org/sites/default/files/sr192.pdf. Sprout, Ron. 2002. "An Overview of Corruption in Central and Eastern Europe and Eurasia:

http://unpan1.un.org/intradoc/groups/public/documents/untc/unpan017022.pdf.

Stefes, Christoph H. 2007. "Measuring, Conceptualizing, and Fighting Systemic Corruption: Evidence from PostSoviet Countries."

http://citeseerx.ist.psu.edu/viewdoc/download?doi=10.1.1.499.8875\&rep=rep1\&type=pdf.

Sudan Tribune. May 3, 2006. "Zenawi's Courts and Political Dissent: 'Ethiopian Judiciary without Justice.'" http://www.sudantribune.com/Zenawi-s-Courts-and-Political,15432.

Svensson, Jakob. 2000. "Foreign aid and rent-seeking." Journal of International Economics 51 (2000) 437-461.

Tamyalew, Arsema. 2010. "A Review of the Effectiveness of the Federal Ethics and Anti-corruption Commission of Ethiopia." The European Union and the International Bank for Reconstruction and Development/World Bank.

https://www.acauthorities.org/sites/aca/files/casestudy/A\%20Review\%20of\%20the\%20Effectiveness\%2 0of\%20the\%20Federal\%20Ethics\%20and\%20Anti-corruption\%20Commission\%20of\%20Ethiopia.pdf.

Tangri, Roger. 2000. The Politics of Patronage in Africa. Parastatals, Privatization, and Private Enterprise. Africa World Press. Oxford: James Currey, Kampala: Fountain, and Trenton, NJ.

\& Andrew Mwanda. 2006. "Politics, Donors and the Ineffectiveness of Anti-Corruption Institutions in Uganda." The Journal of Modern African Studies 44(1). 101-124.

Tecle, Fisseha. 2005. “Ethiopia's Tigrai People's Liberation Front (TPLF) and the Roots of Terrorism in East Africa." http://www.ethiomedia.com/fastpress/tplf vs violence.pdf

Tenna, Seleshi. 2017. "Prospect of FDI-Led Industrialization in Ethiopia (Critical analysis)." http://wazemaradio.com/wp-content/uploads/2017/05/Prospect-of-FDI-Led-Industrialization-inEthiopia-Critical-analysis-.pdf.

Teshome, Wondwosen. 2009. "Electoral Violence in Africa: Experience from Ethiopia." International Journal of Humanities and Social Sciences, Vol. 3, No. 2, pp. 176-201, 2009.

Texeira, Glória, and Ary Ferreira da Cunha. 2015. "Public Governance and Political Corruption: A Framework for Anticorruption Policy." http://www.gestaodefraude.eu/wordpress/wpcontent/uploads/2015/02/wp035.pdf.

Think Tank Fund. October 15, 2015. "Countering State Capture." http://soros.dcleaks.com/fview/President/2015pr/think-tank-fund-countering-state-capture-october15-2015/ttf countering-state-capture-prd-10.15.2015.pdf.

Transparency International, 2001. "Global Corruption Report 2001." http://www.countthecosts.org/sites/default/files/Global\%20Corruption\%20Report\%202001.pdf.

Tronvall K. and L. Aalen. 2009. 'The End of Democracy? Curtailing Political and Civil Rights in Ethiopia', Review of African Political Economy 36(120): 193-207.

Tsegaye, Abdi. 2012. "Ethiopia: Corruption Could Undermine Nation's Development Goals - Sebhat Nega," Addis Fortune, 26, February 2012. http://allafrica.com/stories/201202281072.html.

Transparency International. 2008. Transparency Ethiopia Corruption Diagnostic Baseline Survey-2008Final Report. http://www.iaesafrica.com/

Tura, Hussein Ahmed. 2012. "Overview of Corporate Governance in Ethiopia: The Role, Composition and Remuneration of Boards of Directors in Share Companies." Mizan Law Review Vol. 6 No.1, June 2012. file://C:/Users/shassan/Downloads/81645-194899-1-PB.pdf.

United Nations Economic Commission for Africa. 1996. "Enhancing Ethics in the Ethiopian Civil Serve." 
Hassan: Corruption, State Capture and the Effectiveness of Anti-Corruption Agency in PostCommunist Ethiopia

Upchurch, Martin. 2011. "Wild Capitalism in Post-Communist Transformation: the Case of Serbia." https://eprints.mdx.ac.uk/7981/1/Upchurch and MarinkovicSerbiaER.pdf.

U.S. State Department (Various Annual Issues). Example: 2011 Investment Climate Statement-Ethiopia. http://www.state.gov/e/eb/rls/othr/ics/2011/157275.htm.

Vaughn, Sarah \& Kjetil, Tronvoll. 2003. Structures and Relations of Power: Ethiopia. http://www.gsdrc.org/docs/open/po19.pdf.

. 2015. "2015 Investment Climate Statement - Ethiopia.) http://www.state.gov/e/eb/rls/othr/ics/2015/241555.htm.

Vestal, Theodore. 1999. Ethiopia: A Post-Cold War African State. Praeger Publishers (Westport, Connecticut, United States).

Wassie, Tewodros Ayenew. n.d. "Foreign Aid and the Fiscal Response: Empirical Evidence from Ethiopia." http://www.unitn.it/files/download/20435/wassieresearchproject.pdf.

Wedel Janine R. 2003. "Clans, Cliques and Captured States: Rethinking 'Transition' In Central and Eastern Europe and the Former Soviet Union." Journal of International Development J. Int. Dev. 15, 427-440 (2003). http://www.relooney.info/SI Expeditionary/Post-Conflict-Economic-Development 37.pdf. . 2001." Corruption and Organized Crime in the Post-Communist States: New Ways of Manifesting Old Patterns." http://janinewedel.info/corruption-crime TrendsOrgCrime.pdf.

WikiLeaks.org. September 3, 2011. "Party patronage and foreign assistance in Ethiopia." http://ethiopiantimes.wordpress.com/2011/09/03/wikileaks-party-patronage-and-foreign-assistance-inethiopia/.

. 2011. Party-Statals: How The Ruling Parties' “Endowments” Operate Addis Ababa 00000677001.20 OF 003 Classified By Ambassador Donald Yamamoto for reasons 1.4 (B) and (D). http://wikileaks.org/cable/2009/03/09ADDISABABA677.html.

. May 16, 2008. "Ethiopia: Scholars Describe the Weakening of State Institutions, Economic Mismanagement (Part II of V.)" Classified by former American Ambassador Donald Yamamoto to Ethiopia. https://wikileaks.org/plusd/cables/08ADDISABABA1358 a.html.

Winter, Janice: A climate of corruption, Ethiopian edition. The Daily Maverick. December 12, 2012. http://dailymaverick.co.za/opinionista/2011-12-13-a-climate-of-corruption-ethiopian-edition.

World Bank. 2000. "Anticorruption in Transition: A Contribution to the Policy Debate." http://siteresources.worldbank.org/INTWBIGOVANTCOR/Resources/contribution.pdf.

. n.d. "Chapter 1: The Level and Pattern of Corruption in the Transition Countries." http://siteresources.worldbank.org/ECAEXT/Resources/Anticorruption/chapter1.pdf . n.d. "Unit 1: Introduction to Corruption." http://siteresources.worldbank.org/PSGLP/Resources/corruptionunit1.pdf

. n.d. "Chapter 3: Rise of the Oligarchs under Yeltsin" http://shodhganga.inflibnet.ac.in/bitstream/10603/14866/8/08 chapter\%203.pdf. . 2004. Ethiopia: Legal and Judicial Sector Assessment. http://siteresources.worldbank.org/INTLAWJUSTINST/Resources/EthiopiaSA.pdf. . 1998. ETHIOPIA: Anti-Corruption Report. http://www1.worldbank.org/publicsector/anticorrupt/EthiopiaGCA.pdf. Various Issues, including Annual Country Reports.

Wrong, Michela. 2009. It is Our Turn to Eat: The Story of a Kenyan Whistleblower: A Topical Study Guide on Corruption. National Council of Churches of Kenya, Nairobi, Kenya.

Yakovlev, Evgeny and Ekaterina Zhuravskaya. 2006. "State Capture: From Yeltsin to Putin." Working Paper No 94 CEFIR / NES Working Paper series. http://pdc.ceu.hu/archive/00004512/01/WP94 Zhuravskaya Yakovlev.pdf. 
Hassan: Corruption, State Capture and the Effectiveness of Anti-Corruption Agency in PostCommunist Ethiopia

Young, John. 1997. "Development and Change in Post-Revolutionary Tigray." Journal of Modern African Studies. 35 (1), 81-99.

. 2006. Peasant Revolution in Ethiopia: The Tigray People's Liberation Front, 1975-1991

Cambridge University Press, Apr 20, 2006

Meles: 2012 Address Parliament I and II: (Feb, 9, 20012; March 17, 2012; See also this, this, this, this, this, this and various Speeches to Parliament and Businesspersons such as:

http://sodere.com/video/ethiopian-pm-meles-zenawi-3; http://sodere.com/video/ethiopian-pm-meleszenawi-1.

Zelelew, Mekonen, Former member of the TPLF and financial administrator (personal communication. December 11, 2009.)

Zenebe, Wudineh (July 15, 2008)." Businesses to Raise Funds to Finance EPRDF HQs, Training Centre." http://www.africa.co.ee/2008/07/businesses-to-raise-funds-to-finance-eprdf-has-training-centre.html; or http://www.ethiopiainsight.com/news/funds to finance eprdf hqs.htm,

Zerai, Abdissa. 2016. "Ethiopia in a State of Interregnum." December 10, 2016. http://www.ethiomedia.com/1000codes/8015.html. 